\title{
Closer Than We Think: visioni del futuro dell'alimentazione nelle illustrazioni di Arthur Radebaugh
}

\author{
Daniele Rossi
}

\section{Abstract}

Per poter sperimentare nuovi scenari progettuali e nuove strategie comunicative del patrimonio enogastronomico, attraverso l'impiego di tecnologie innovative, è necessario rivolgersi al passato e osservare, con la giusta distanza critica, quali sono state le visioni del futuro nel campo della produzione e consumo del cibo. L'articolo pertanto intende porre le basi per una esaustiva attività di analisi di alcuni scenari applicativi prefigurati nel passato nel campo della produzione e consumo di cibo. Per tale motivo sarebbe forse più opportuno parlare di paleofuturo ossia il futuro situato cronologicamente nei tempi che ora noi stiamo vivendo e immaginato in un tempo lontano.

In tale cornice, lo studio del paleofuturo, può aiutarci a riannodare i fili con il passato al fine di trarne degli insegnamenti e di comprendere come la crescita esponenziale di alcune tecnologie abilitanti possa in qualche caso essere indirizzata verso contesti non del tutto prevedibili.

In particolare, ci si focalizzerà sull'opera di Arthur Radebaugh, un illustratore americano che intorno al 1950 ha raccontato, in forma di vignetta, alcuni dei progressi scientifici del tempo, prefigurando possibili scenari di vita quotidiana.

\section{Parole chiave}

fantascienza, illustrazione, paleofuturo, futurologia, Arthur Radebaugh.

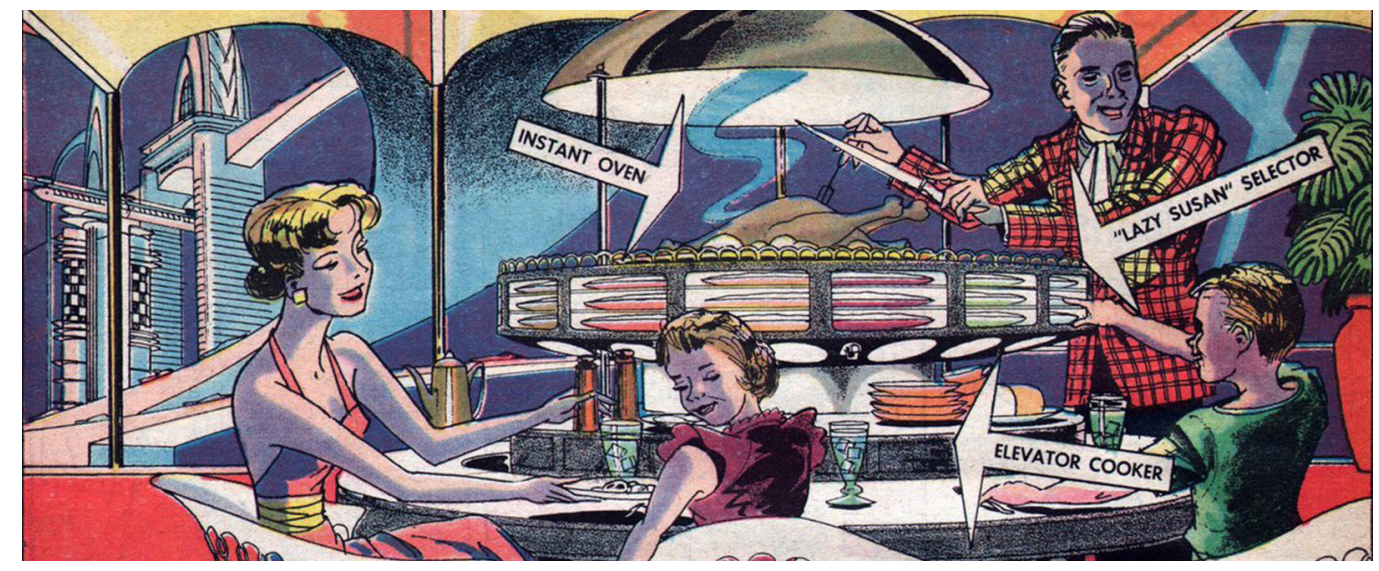




\section{Introduzione}

Secondo Isaac Asimov [1986], Jules Verne nel momento in cui decise di scrivere quelli che il suo editore chiamava "viaggi straordinari", popolati da viaggi al centro della terra o in fondo al mare o ancora sulla luna, divenne il primo futurologo nel senso moderno del termine. Fu infatti il primo a considerare il futuro come un luogo plasmato sulla base del progresso tecnologico e delle scoperte scientifiche che stavano accompagnando i suoi anni di vita. Meno di trent'anni più tardi, intorno al 1890, Herbert Georges Well si spinse ancora più in là con l'immaginazione, provando a progettare scenari non sostenibili dalla scienza a lui contemporanea quali invasioni aliene o viaggi nel tempo. Tuttavia, seppur impossibili, tali scenari contribuirono nel far crescere nel suo pubblico una fiducia incondizionata su un futuro tecnologico.

E chiaro a molti che la fantascienza letteraria sia stato il terreno privilegiato dove molti autori hanno potuto allenare le proprie capacità immaginative alimentate dai progressi nel campo delle scienze e delle tecniche. Gli stessi autori hanno anticipato numerose delle scoperte tecnologiche del $X X$ secolo. Viaggi nello spazio, automi, robot o armi nucleari prima che nei laboratori sono stati concepiti nella testa di pochi visionari.

Dopo la Seconda Guerra Mondiale, ovvero dopo che la bomba atomica di Hiroshima aveva bruscamente spostato il futuro dalle sognanti pagine dei libri di fantascienza alla tragica realtà degli avvenimenti, la futurologia divenne quasi una scienza che, sostenuta da dati, statistiche e proiezioni, tentò di determinare cosa potesse accadere in un futuro prossimo con lo scopo di sostenere, ad esempio, scelte e politiche di sviluppo industriale.

Fig. I. La Cena Chimica, En l'an 2000 ( ( 899).

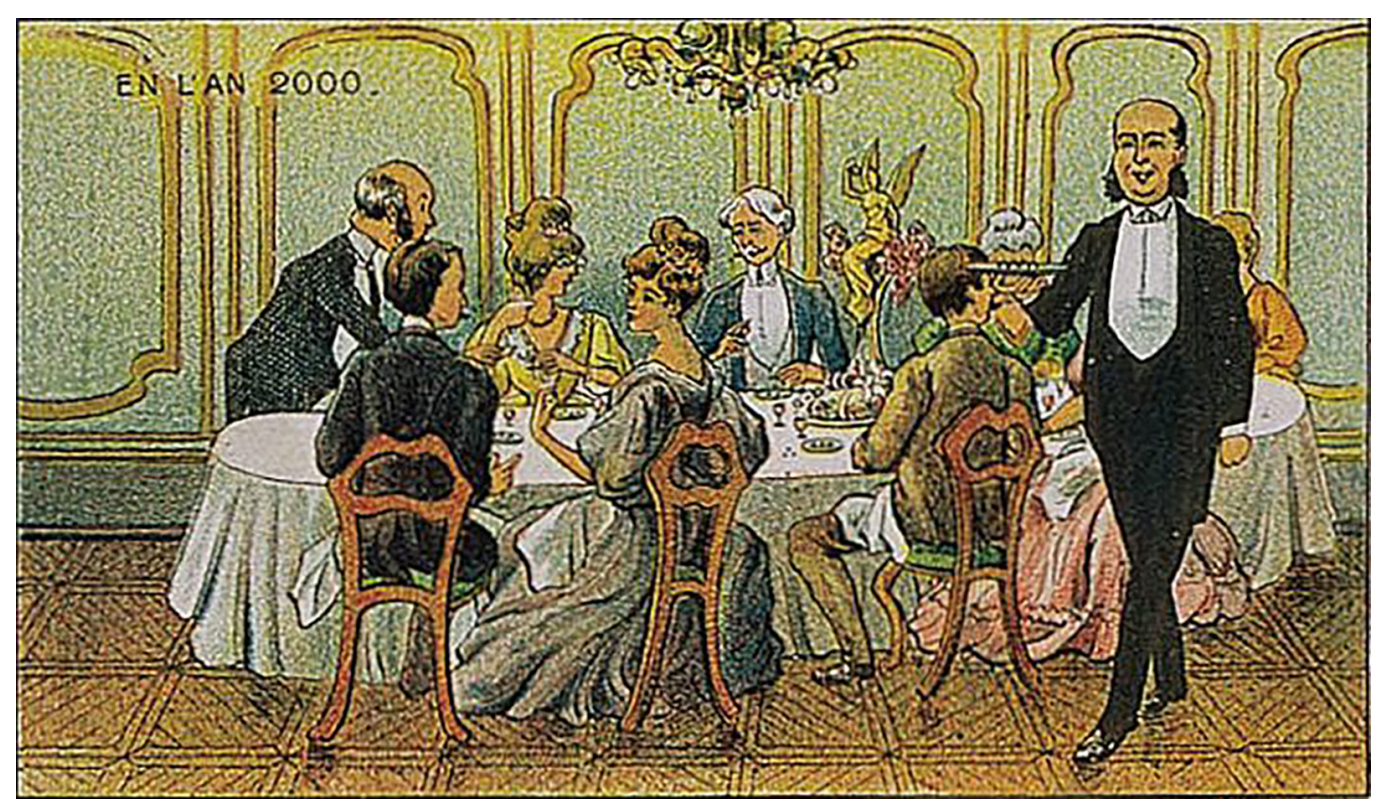

Immaginare il futuro dell'alimentazione

Nella finzione letteraria prima e cinematografica poi, l'atteggiamento verso ciò che riguarda l'alimentazione e i modi di produrla e fruirla è cambiato molto negli ultimi centocinquanta anni.

Nel 1888, in Guardando indietro 2000-1887, l'autore Edward Bellamy, tra le molte intuizioni, immaginò, in linea con il suo pensiero socialista, utopiche cucine pubbliche dove poter mangiare gratuitamente dopo essere andato in pensione a 45 anni. Sessant'anni dopo, l'ossessione per l'ottimizzazione e l'efficienza, riempì i racconti di tavole imbandite con pillole e surrogati, mentre a partire dagli anni 70 , per la paura di rimanere senza cibo per il sovrap- 
popolamento della Terra, gli autori di fantascienza si rivolsero alle alghe, agli insetti e a fonti proteiche alternative [Novak 20 I4].

Tra i futurologi, coloro i quali si sono cimentati con il difficile compito di tradurre in segni alcune speculazioni teoriche basate su scoperte scientifiche o tecnologie sperimentali hanno dovuto ri-mediare il proprio regime scopico fondato sulla cultura visuale del tempo, con la necessità di illustrare un futuro verosimile.

Là dove lo scrittore di romanzi di genere poteva permettersi visioni sfumate l'illustratore doveva trovare forme esatte e occasioni progettuali basandosi su un'interpretazione "creativa" di alcune tecnologie di frontiera.

È il caso di, Jean Marc Cotè ad esempio, che a partire dal 1899 insieme ad altri colleghi e collaboratori [I], tentò di rappresentare, su delle cartoline inserite all'interno di pacchetti di sigarette, alcune visioni di quella che sarebbe stata la vita nell'allora lontano 2000. Tra le scene di vita raffigurate, non poteva mancare la rappresentazione di un pranzo degli anni 2000 a base di pillole e confetti. La scoperta dell'esistenza delle vitamine risale al 1896, owvero tre anni prima questa vignetta, mentre già nel corso del XIX secolo si era scoperto che gli alimenti erano composti da proteine, grassi e carboidrati.

L'illustratore era evidentemente a conoscenza di tali scoperte e così raffigura una tavolata tradizionale occupata da ospiti nei vestiti dell'epoca e serviti da camerieri attrezzati con vassoi contenenti sole pillole (fig. I). In un'altra cartolina si scopre quella che doveva essere il laboratorio dove 'cucinare' tali pillole. Un laboratorio popolato da alambicchi, serbatoi e altre attrezzature chimiche piuttosto che da pentole e utensili da cucina (fig. 2).

In entrambe le vignette l'autore preconizza quella che sarà una pratica comune del XX secolo, ovvero quella della scomposizione molecolare degli alimenti non tanto per nutrirsene durante i pasti (se non in forme alternative, si pensi ad esempio agli integratori proteici e vitaminici) quanto piuttosto per sofisticare colture o allevamenti con vitamine e minerali o altre forme di additivi chimici.

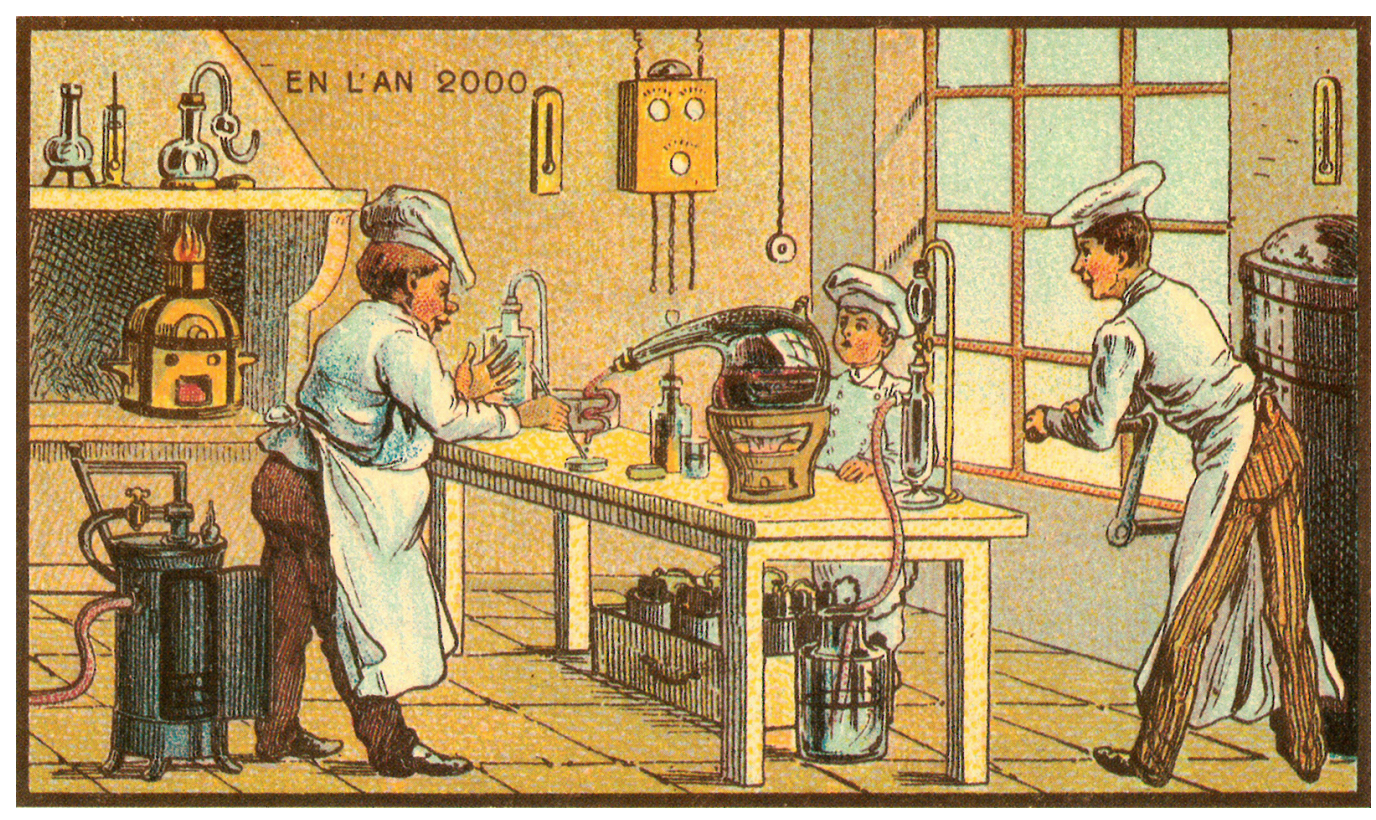

\section{Arthur Radebaugh}

Circa 60 anni più tardi si cimenta nello stesso esercizio predittivo, un illustratore, conosciuto per lo più perché tra fu tra i primi a utilizzare in forma artistica l'aerografo [2], che sarebbe diventato, nell'immediato dopoguerra, uno dei personaggi simbolo di un'ottimistica tecno-utopia. 
Si tratta di Arthur Radebaugh (fig. 3). Nato nel 1906 in Michigan, si trasferì a Chicago per frequentare il Chicago Art Institute nel 1925, scuola che gli permise di sperimentare intorno all'uso dell'areografo e che però abbandonò prematuramente. La sua passione per il disegno non svanì, tutt'altro, tanto che a metà degli anni Trenta, si affermò come illustratore freelance di successo, lavorando per la United AirLines, e la Burlington-Pacific Road e per riviste quali Esquire e MoToR.

Durante la Seconda Guerra Mondiale si arruolò nell'Army Ordinance Department, dove mise a disposizione il suo talento visionario nel reparto Design \& Visualization con il compito di immaginare nuove tipologie di strumenti bellici. È qui che, lavorando fianco a fianco con scienziati e ingegneri, che probabilmente si forma la sua capacità di tradurre su carta, e in chiave fortemente tecnologica, alcune visioni di un futuro prossimo.

A lui si deve l'utilizzo, all'interno degli abitacoli di veicoli di guerra, di luci ultraviolette per 'illuminare' in maniera che non fossero notati da nemici, i cruscotti e le strumentazioni di guida. L'esperienza nell'esercito contribuì ad arricchire le sue capacità e il suo stile di disegno, tanto da fargli intraprendere a tempo pieno l'attività di illustratore di un tempo futuro.

Nel 1958, infatti, cominciò la sua produzione di vignette illustrate dall'illuminante titolo Closer Than We Think, in cui, sulla base di conoscenze scientifiche acquisite durante continui viaggi tra centri di ricerca e laboratori universitari, disegnava impossibili scenari di vita domestica e lavorativa. Le sue vignette raggiungevano settimanalmente circa diciannove milioni di lettori in un periodo di tempo compreso tra il 1958 e il 1962, quando, a causa di problemi di salute, fu costretto a interrompere la sua produzione [3].

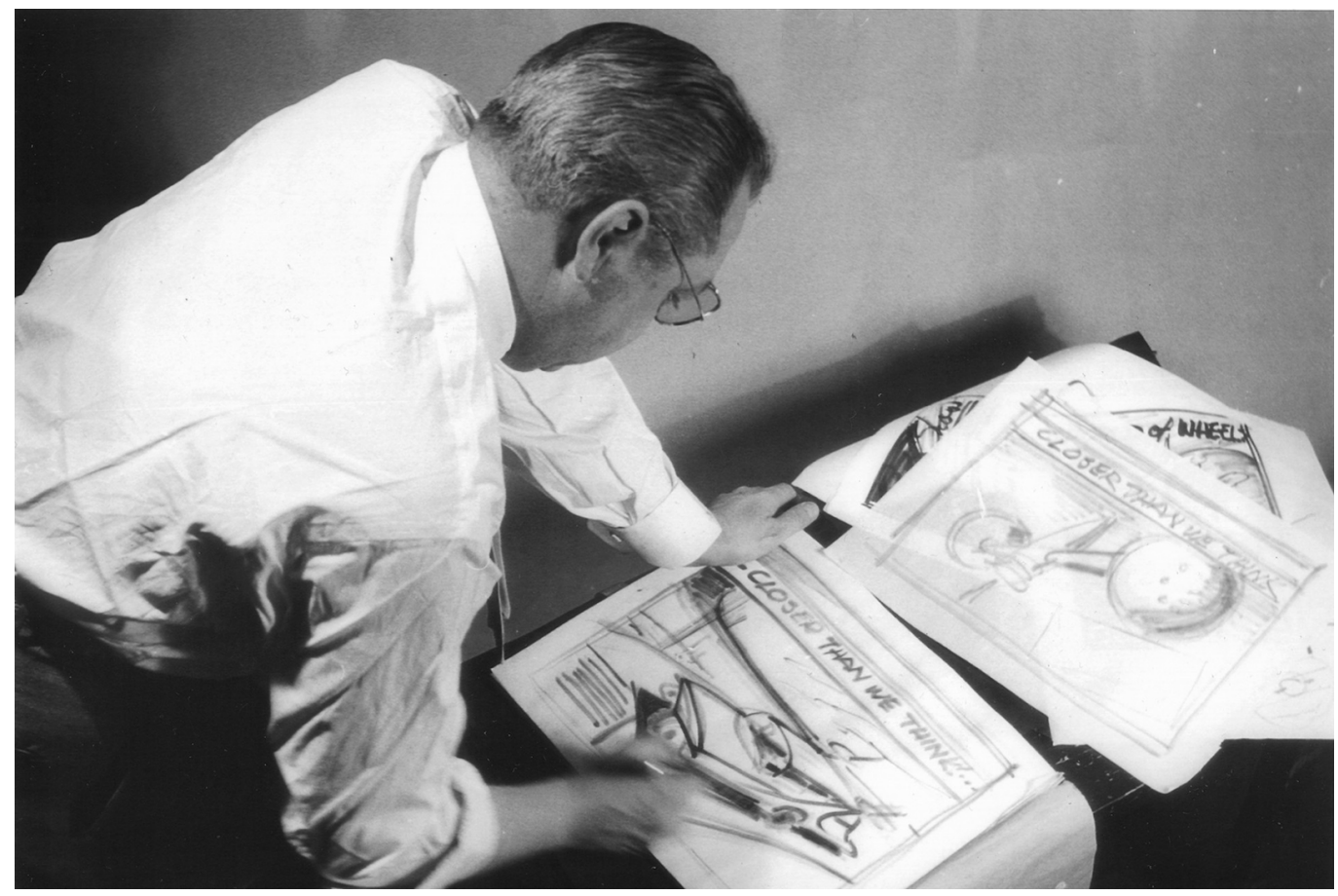

\section{Closer Than We Think}

Concepita per essere distribuita nei quotidiani americani e canadesi, la serie Closer Than We Think, rappresenta un perfetto compendio delle possibilità di ciò che in potenza avrebbe potuto essere la vita in un futuro prossimo.

L'interpretazione di Radebaugh combinava il codice streamline di cui era ancora intrisa la cultura progettuale negli Stati Uniti degli anni '60, con le suggestioni generate dai reali progressi della scienza e della tecnica. 
Da un punto di vista grafico la composizione della vignetta rispettava un layout pressoché costante. La strip si componeva di una unica vignetta a colori accompagnata da un blocco di testo didascalico dove l'autore integrava con dati, nomi di scienziati o di laboratori, la lettura e la comprensione di ciò che era illustrato. A completare la composizione, il titolo in maiuscolo della serie su un rettangolo colorato posto in alto sul lato lungo del rettangolo complessivo di ingombro.

Tra le più di cento vignette disegnate, quelle che preconizzano i cambiamenti nel modo di produrre, distribuire o assimilare alimenti sono circa una dozzina.

I sotto temi trattati sono appunto tre e rispondono essenzialmente a tre domande. Come soddisfare la crescente domanda di cibo dovuto all'aumento della popolazione mondiale? Come saranno riorganizzate le catene di distribuzione del cibo al dettaglio? Quali saranno i modi di preparare e consumare gli alimenti in ambiente cucina?

Alla prima domanda rispondono una serie di vignette che affrontano il tema dell'industrializzazione e dell'automazione agricola. In Factory Farms, una vignetta pubblicata nel 196I, il testo di accompagnamento cita testualmente: "L'agricoltura nel futuro sarà così meccanizzata che le fattorie assomiglieranno sempre più alle fabbriche. Colture e allevamenti saranno controllati seguendo programmi definiti in base a determinate condizioni. 'Sensori' e altri dispositivi di controllo saranno adattati secondo i requisiti dell'agricoltura di precisione. Tali dispositivi sostituiranno gli umani nelle decisioni e reagiranno immediatamente ai mutamenti dovuti alle condizioni del terreno, alla maturazione dei raccolti, ai livelli di umidità, alle condizioni atmosferiche, alle necessità alimentari del bestiame, ecc.".

Quella che noi oggi chiameremmo una fattoria intelligente, viene rappresentata con una vista prospettica che mostra al centro della scena un edificio circolare. Questo sembra essere la centrale di controllo che governa l'attività di trasferimento automatico del mangime da cinque enormi plastic silos verso i granai per il bestiame, mentre un treno su monorotaia aerea trasporta materiale da una parte all'altra della fattoria. In primo piano invece, la scena mostra un ricercatore, nel suo laboratorio, nell'atto di pungere con una siringa un pomodoro, frutto di un qualche esperimento che ne ha vistosamente aumentato le dimensioni (fig. 4).

Il gigantismo dei prodotti della terra e il superamento della stagionalità delle colture sono dei topos che ricorrono anche in un'altra vignetta del 1962 intitolata Colossal Crops in cui le

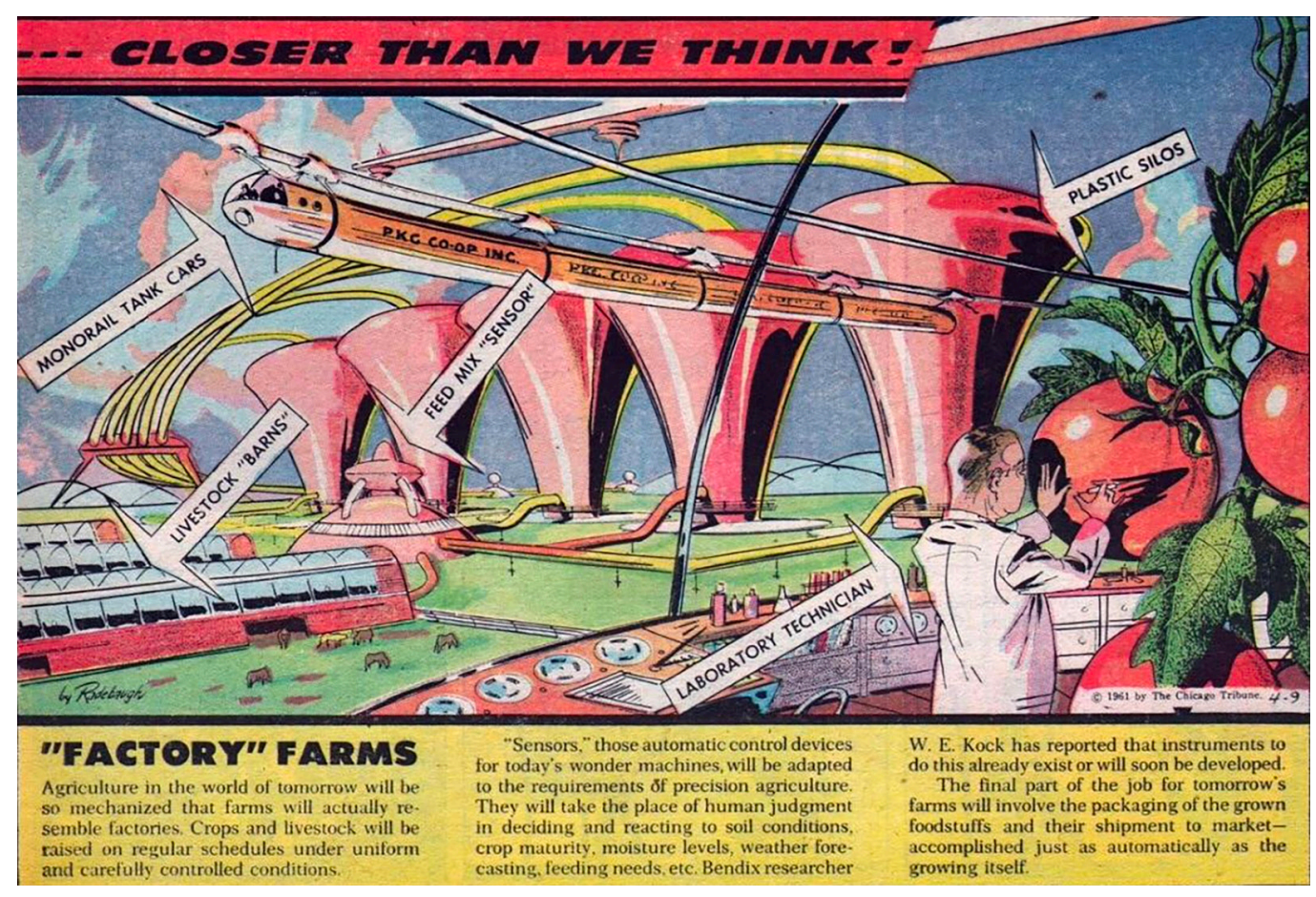




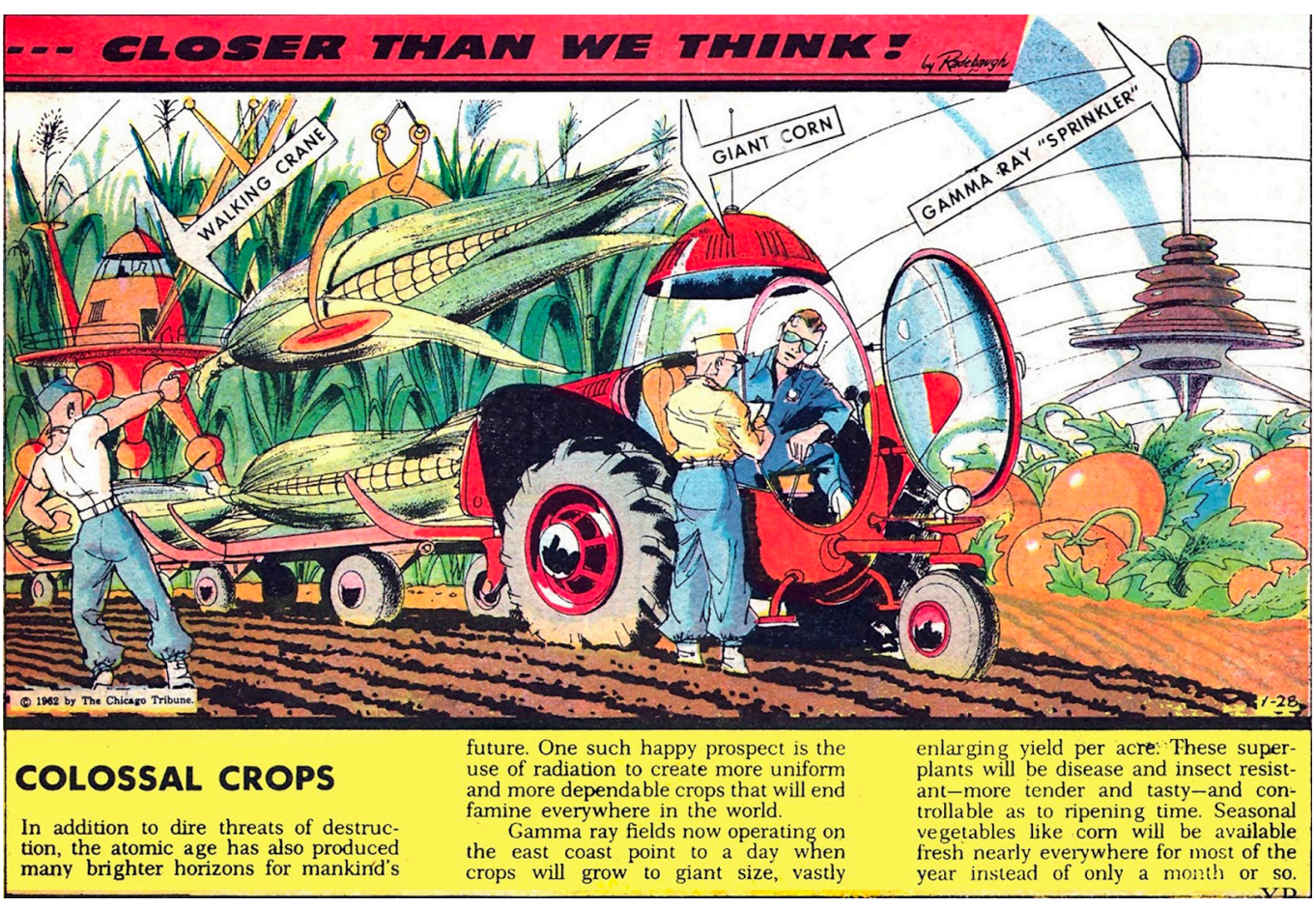

radiazioni nucleari, provenienti da un'antenna che emette raggi gamma, alimentano e fanno crescere a dismisura i fiori del mais, tanto da rendere necessario l'utilizzo di gru semoventi e trattori per poterli raccogliere (fig. 5). In Fat Plants e Meat Beets, Radebaugh invece ipotizza che in un futuro prossimo, la crescita della popolazione costringerà a sostituire, o per lo meno affiancare, la carne, con proteine aromatizzate di origine vegetale (fig. 6).

Nelle vignette dedicate alla distribuzione del cibo, Radebaugh si occupa di illustrare le modalità di vendita al dettaglio dei prodotti alimentari. L'immagine ricorrente è quella del self-service declinato in diverse forme. In Corner Grocermat, l'autore scrive: "Ecco un'idea per ren-

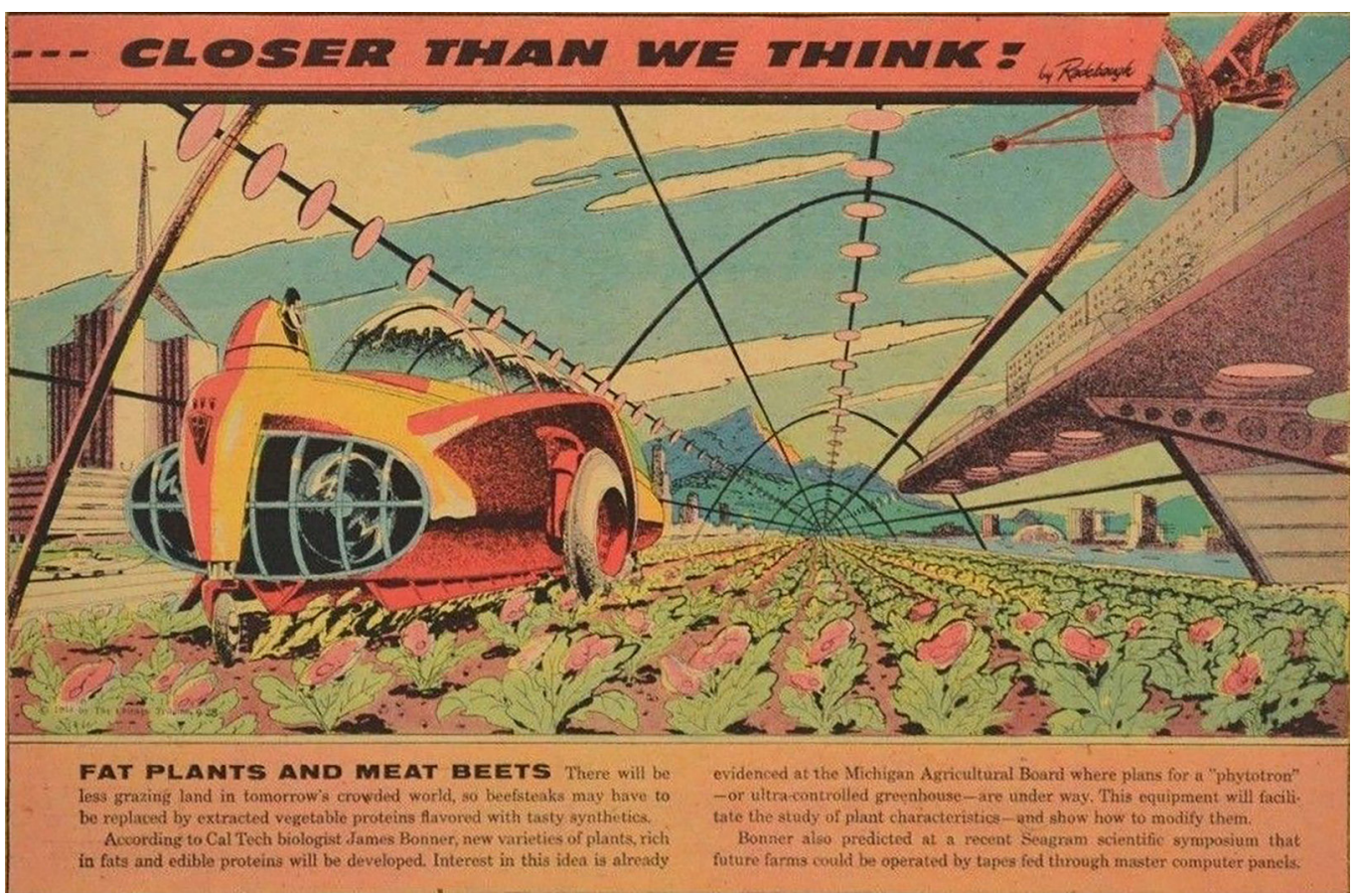


Fig. 7. Corner Grocermat, Closer Than We Think (1958).

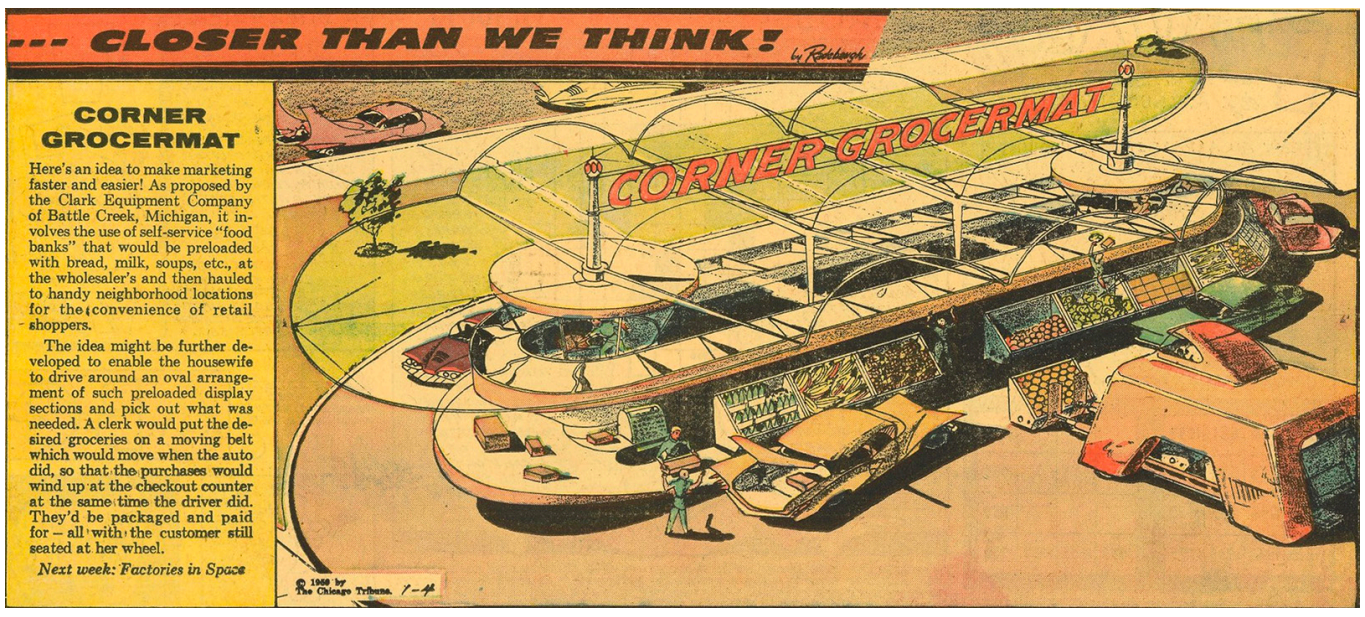

dere il commercio più veloce e più facile! Come proposto dalla Clark Equipment Company di Battle Creek in Michigan, prevede l'uso di 'casse alimentari' self-service da caricare con pane, latte, zuppe, ecc., dal grossista e da trasportare comodamente nei mercati di quartiere per la vendita al dettaglio. L'idea potrebbe essere ulteriormente sviluppata per consentire alla casalinga di guidare intorno a una struttura ovale allestita con tali banchi alimentari e scegliere ciò che vogliono. Un commesso metterà la spesa su un nastro trasportatore che si muove accompagnando il percorso dell'auto in modo che gli acquisti arriveranno alla cassa insieme all'automobile. I beni saranno poi impacchettati e pagati, il tutto con il cliente ancora seduto al volante".

L'illustrazione mostra un avveniristico stand di mercato alimentare composto da una struttura coperta allungata caratterizzata da due anelli. In quello più basso vengono caricati, mediante avveniristici veicoli streamlined, casse piene di alimenti mentre nell'anello superiore un nastro trasportatore conduce in cassa gli articoli selezionati dagli utenti che, senza scendere dall'auto, indicano a degli operatori, quale prodotto vogliono acquistare (fig. 7). In maniera del tutto analoga, il Drive-In Super Supermarket può essere considerato un'evoluzione del

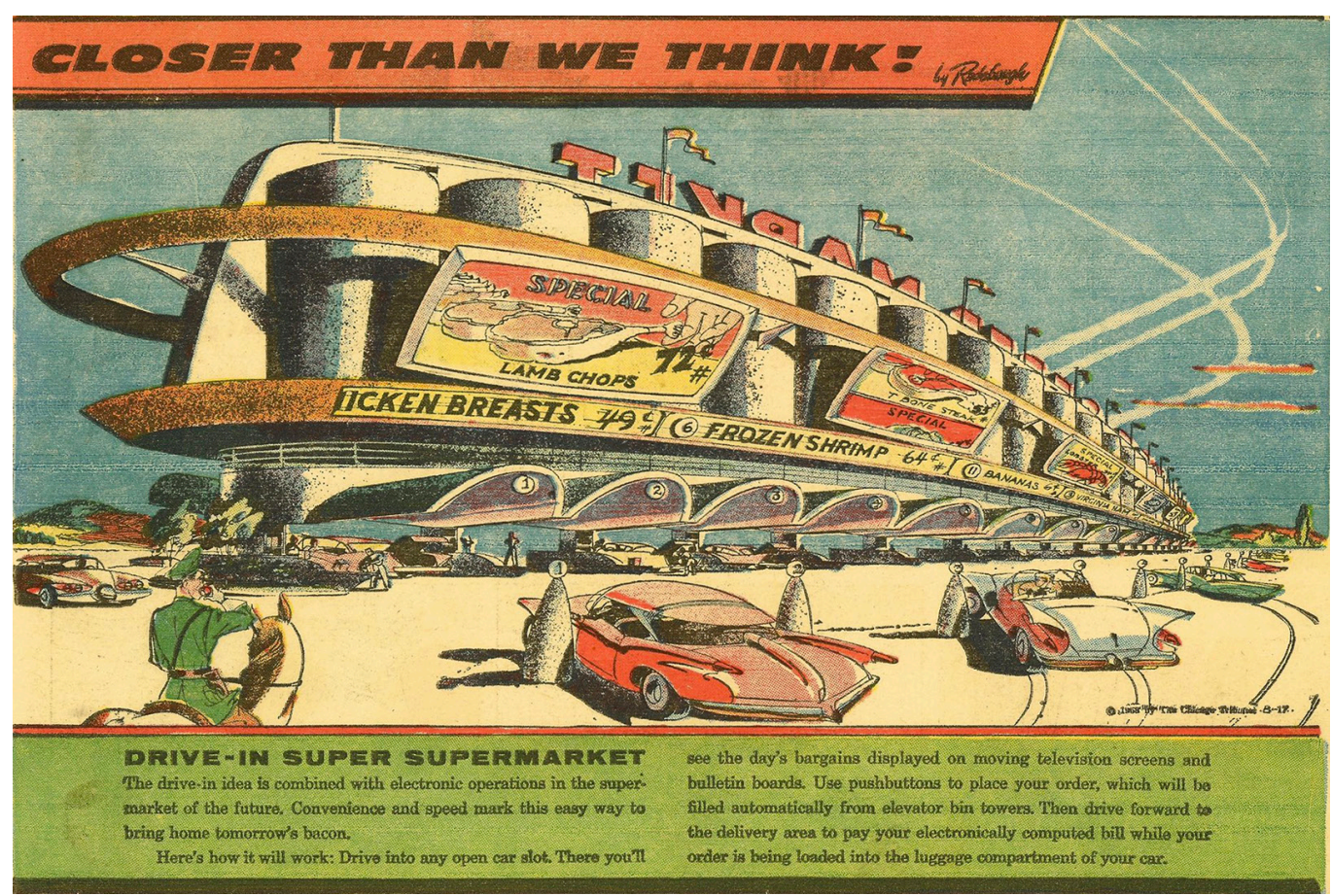


Fig. 9. All-Service Stations, CloserThan We Think (1959).

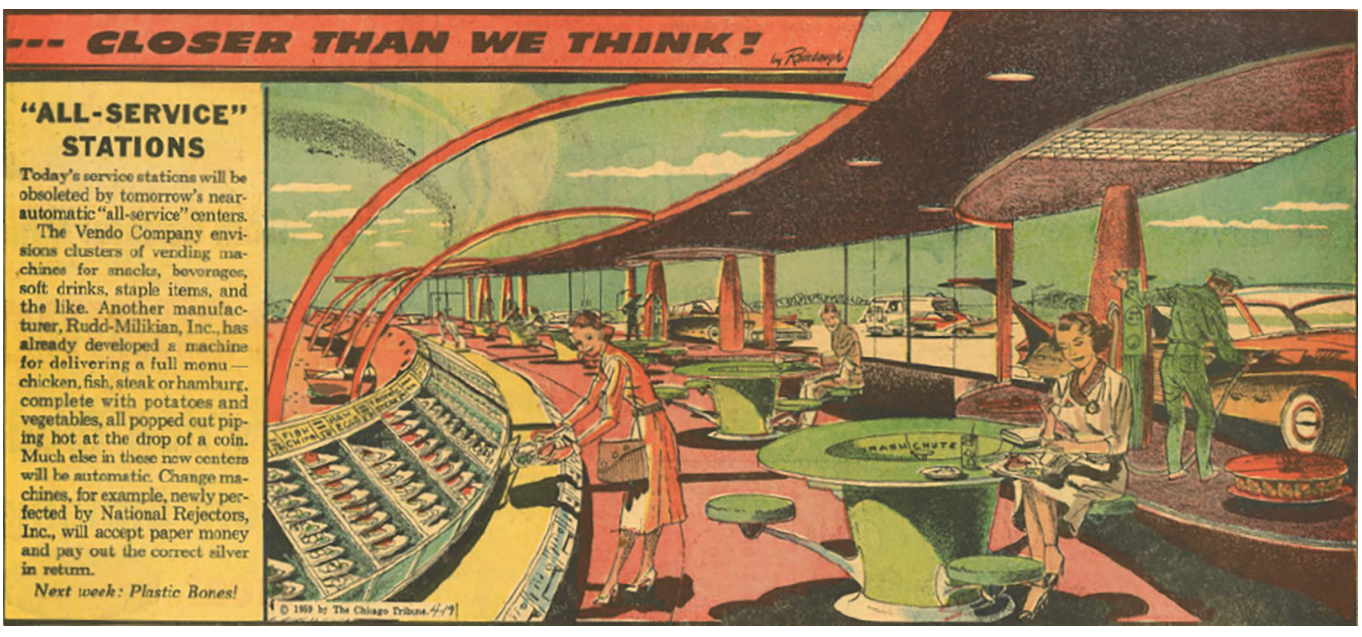

Corner Grocermat. In questo caso il cliente, arrivando in auto, avrebbe parcheggiato in un apposito stallo dove, dopo aver lette le offerte su dei monitor, avrebbe effettuato gli ordini mediante una pulsantiera. Dopo aver ordinato si sarebbe spostato in un'altra postazione per il pagamento e per consentire ai commessi di caricare gli acquisti direttamente nel bagagliaio dell'auto (fig. 8).

in All-Service Stations la visione di Radebaugh si concentra invece nell'immaginare distributori automatici di cibi precotti pronti al consumo. Distributori che completeranno l'offerta delle stazioni di servizio del futuro, ristorando i viaggiatori in attesa che l'auto venga rifornita (fig. 9). Per quel che riguarda, infine, la preparazione e il consumo del cibo in ambiente domestico, Arthur Radebaugh disegna due vignette tese entrambe a enfatizzare l'uso di automatismi e robot che saranno in grado, a suo dire, di aiutare la donna in cucina. In particolare, in Robot Housemaid l'autore con toni trionfalistici annuncia che: "Non ci saranno più problemi con la servitù nella tua casa del futuro. Impegnate un robot per cucinare, apparecchiare la tavola, sparecchiarla, lavare i piatti e riporli". Nella vignetta tale robot assume le sembianze non antropomorfe di un cono che si sposta nella casa mediante cuscinetti d'aria e capace di vedere intorno a sé tramite telecamere posizionate sul vertice. Lo stesso robot trasporta i piatti da servire in tavola con un vassoio circolare posto nella parte superiore del cono (fig. I0). In

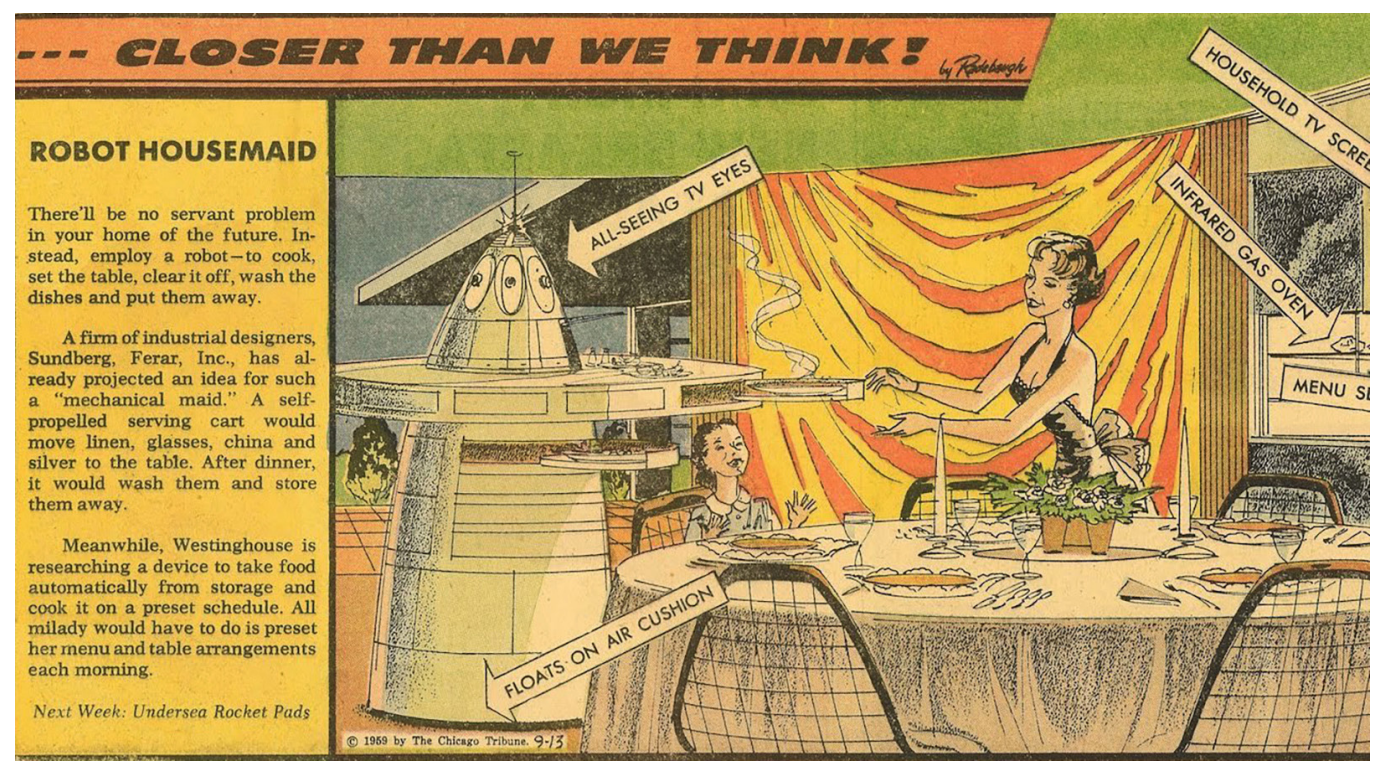

Fig. 10. Robot Housemaid (1959). 
Instant Cookers, si osserva una famiglia seduta intorno a un tavolo occupato da un imponente forno circolare sovrastato da una cappa cromata e capace di cuocere istantaneamente una varietà di piatti selezionabili, compartimentati nel forno stesso e selezionabili al tocco. II resto della vignetta ci mostra dalle ampie finestrature della cucina rampe autostradali e grattacieli che sembrano usciti direttamente da qualche tavola di Hugh Ferriss (fig. I I).

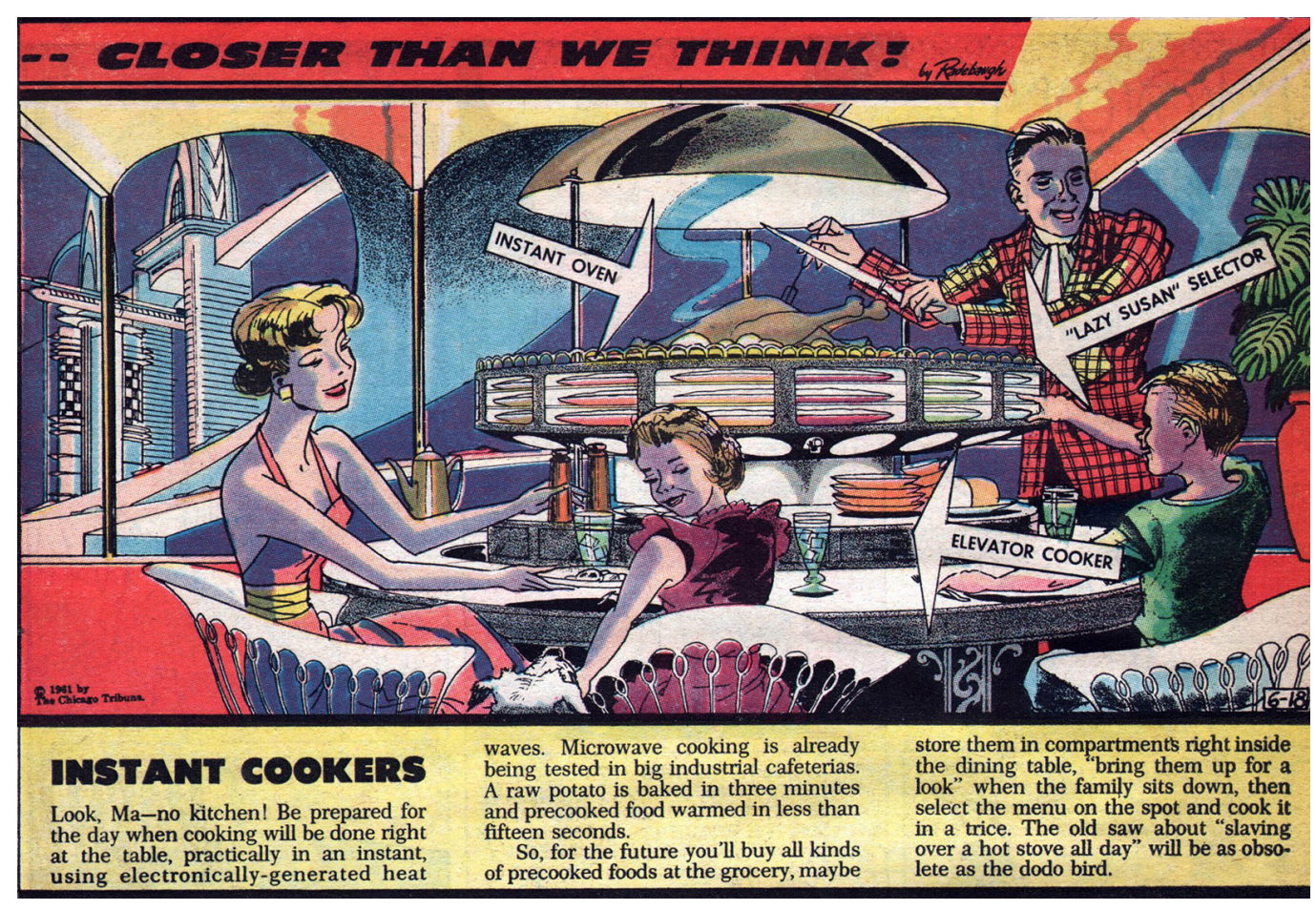

\section{Conclusioni}

La sperimentazione di nuovi scenari progettuali per il patrimonio enogastronomico attraverso l'impiego di tecnologie innovative non può non passare attraverso l'analisi di quelle che sono state, in passato, le visioni del futuro [4]. Così come uno scavo archeologico ci permette di scoprire tracce di un passato vissuto, così lo studio del paleofuturo ci aiuta a comprendere determinati scenari filtrati dal period eye dell'epoca. Ognuno avrà trovato, nelle vignette sopra illustrate, riscontri e analogie con le tecnologie che si sono realmente sviluppate e che legittimano le capacità immaginative di figure, come quelle di Arthur Radebaugh, di immaginare il futuro, prefigurando scenari di vita quotidiana.

Lo scopo di tale analisi non è però aneddotico. Robot domestici, distributori automatici, cibi OGM, microonde, nastri trasportatori o additivi proteici sono entrati stabilmente nelle nostre vite così come anticipato da molti scienziati. II merito di Radebaugh è stato quello di aver calato su foglio alcune intuizioni e scoperte tecnologiche, o avere saputo immaginare utilizzi diversi di tali tecnologie. Il disegno, in questo caso il 'disegno di visione', rappresenta ancora una volta un luogo privilegiato di sperimentazione progettuale e un territorio di esperienza formativa.

Note

[I] La serie si intitola appunto En l'an 2000 e avrebbe dovuto celebrare l'avvento del Novecento. L'attribuzione delle vignette è incerta. Asimov [1986] sostiene che Cotè è l'autore di tutte le cartoline mentre più probabilmente sono diversi gli autori come si può facilmente intuire da alcune differenze grafiche e di impostazione. Wikimedia Commons in <https://commons. wikimedia.org/wiki/Category:France_in_XXI_Century_(fiction)? uselang=it> (consultato il 20 febbraio 2020) le attribuisce a tre autori differenti: J. M. Cotè, J.Villemard e F. Foliot. 
[2] II disinvolto utilizzo dell'aerografo, unitamente a quello della luce nera a ultravioletti, spinse un giornalista di un giornale di Portsmouth nel 1947, a impiegare il termine imagineering, molti anni prima che questo venisse 'brevettato' dalla Disney. Nell'articolo, intitolato Black Light Magic, si sottolineava la sapienza di Radebaugh nellintersecare genio artistico e strumentazioni tecnologicamente avanzati. Cfr. <https://paleofuture.gizmodo.com/word-origins-imagineering-1940s-5 I26306 I8> (consultato il 20 febbraio 2020)

[3] Arthur Radebaugh morì in povertà nel 1974 e il suo lavoro dimenticato fino al 200 I quando Tod Kimmel venne casualmente in possesso dei negativi della maggior parte della sua collezione. La storia completa della 'riscoperta' di Arthur Radebaugh è stata narrata nel 2018 nel documentario CloserThan We Think del regista Brett Ryan Bonowicz.

[4] L'autore del presente articolo è PI di un progetto di ricerca intitolato Food and Wine Heritage in the Marche Region: Digital Storytelling Through Virtual and Augmented Reality finanziato nell'ambito del bando istituito dall'Università di Camerino per l'attribuzione del Fondo di Ateneo (FAR) 2018. Durata: 24 mesi (I/2/2019-I/2/ 202I).

\section{Riferimenti bibliografici}

Asimov I. (1986). Futurdays. London:Virgin Books.

Belasco W. (2006). Meals to Come. Oakland: University of California Press.

Corn J.J., Horrigan B. (1984). Yesterday Tomorrow, Past Vision of the American Future. Baltimore: Johns Hopkins University Press.

\section{Sitografia}

Novak M. (I 8 novembre 20 I4). Meal-in-a-pill:A staple of science fiction. <https://www.bbc.com/future/article/20 I 2022 I-foodpills-a-staple-of-sci-fi> (consultato il 20 febbraio 202I).

<http://arthur-radebaugh.blogspot.com/ > (consultato il 20 febbraio 202 I).

Novak M. (Ed.). Paleofuture Magazine, Issue I: Food. <https://paleofuture.com/blog/20 I I/4/4/paleofuture-magazine-issue- I-food.html> (consultato il 20 febbraio 202I).

Autore

Daniele Rossi, Università di Camerino, daniele.rossi@unicam.it

Per citare questo capitolo: Rossi Daniele (202I). Closer Than We Think: visioni del futuro dell'alimentazione nelle illustrazioni di Arthur Radebaugh Closer Than We Think: visions of the future of food in the illustrations of Arthur Radebaugh. In Arena A., Arena M., Mediati D., Raffa P. (a cura di). Connettere. Un disegno per annodare e tessere. Linguaggi Distanze Tecnologie. Atti del $42^{\circ}$ Convegno Internazionale dei Docenti delle Discipline della Rappresentazione/Connecting. Drawing for weaving relationship. Languages Distances Technologies. Proceedings of the $42^{\text {th }}$ International Conference of Representation Disciplines Teachers. Milano: FrancoAngeli, pp. 1085-1 104. 


\title{
Closer Than We Think: Visions of the Future of Food in the Illustrations of Arthur Radebaugh
}

\author{
Daniele Rossi
}

\section{Abstract}

In order to experiment new design scenarios and new communication strategies of the enogastronomical heritage, through the use of innovative technologies, it is necessary to look back to the past and observe, with the right critical distance, what have been the visions of the future in the field of food production and consumption. The article therefore intends to lay the foundations for a comprehensive analysis of some application scenarios foreshadowed in the past in the field of food production and consumption.

For this reason, it would be more appropriate to speak of paleofuture, that is the future located chronologically in the times that we are now living and imagined in a distant time.

In this framework, the study of the paleofuture, can help us to tie the threads with the past in order to draw lessons and understand how the exponential growth of some enabling technologies may in some cases be directed towards contexts not entirely predictable.

In particular, we will focus on the work of Arthur Radebaugh, an American illustrator who around 1950 told, in the form of cartoons, some of the scientific advances of the time, prefiguring possible scenarios of everyday life.

Keywords

science fiction, illustration, paleofuture, futurology, Arthur Radebaugh.

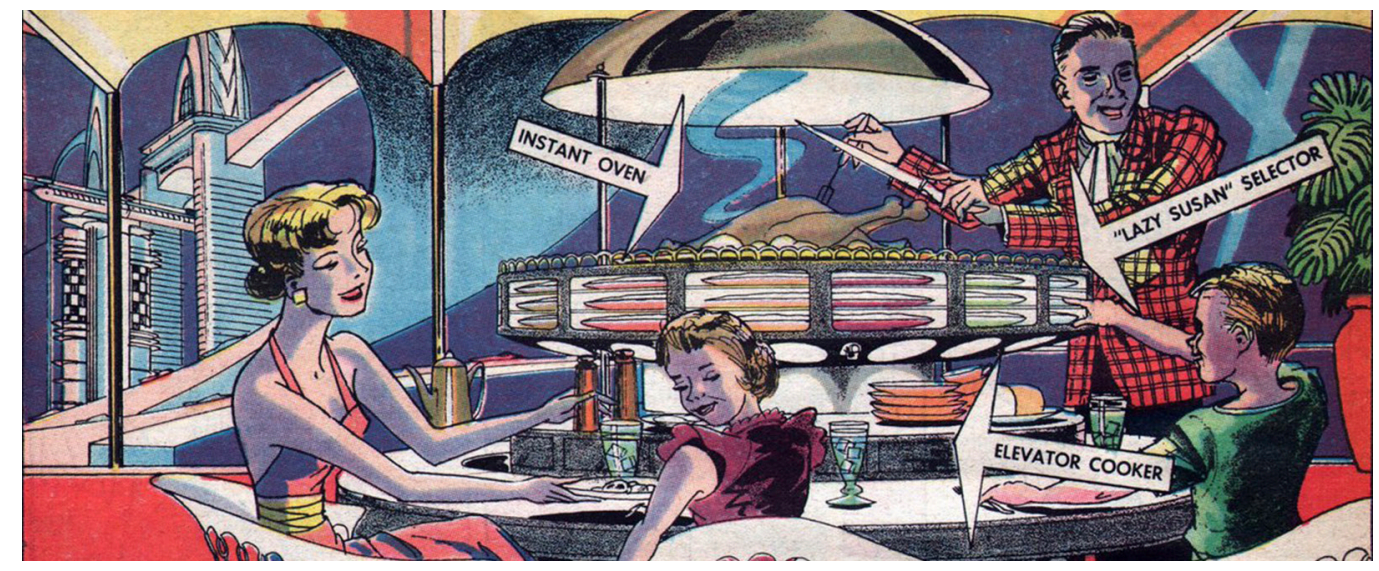




\section{Introduction}

According to Isaac Asimov [1986], Jules Verne in the moment he decided to write what his publisher called "extraordinary journeys", populated by trips to the center of the earth or to the bottom of the sea or even to the moon, became the first futurologist in the modern sense of the term. In fact, he was the first to consider the future as a place shaped on the basis of technological progress and scientific discoveries that were accompanying his years of life. Less than thirty years later, around 1890, Herbert Georges Well went even further with his imagination, trying to design scenarios not sustainable by contemporary science such as alien invasions or time travel. However, while impossible, such scenarios contributed to his audience's unwavering belief in a technological future.

It is clear to many that literary science fiction has been the privileged terrain where many authors have been able to train their imaginative abilities fueled by advances in science and technology. The same authors anticipated many of the technological discoveries of the 20th century. Space travel, automata, robots or nuclear weapons were conceived in the heads of a few visionaries before they were conceived in laboratories.

After the Second World War, after the atomic bomb of Hiroshima had abruptly shifted the future from the dreamy pages of science fiction books to the tragic reality of events, futurology became almost a science that, supported by data, statistics and projections, tried to determine what could happen in the near future in order to support, for example, choices and policies of industrial development.

Fig. I. Chemical Dinner, Enl'an 2000 (1899)

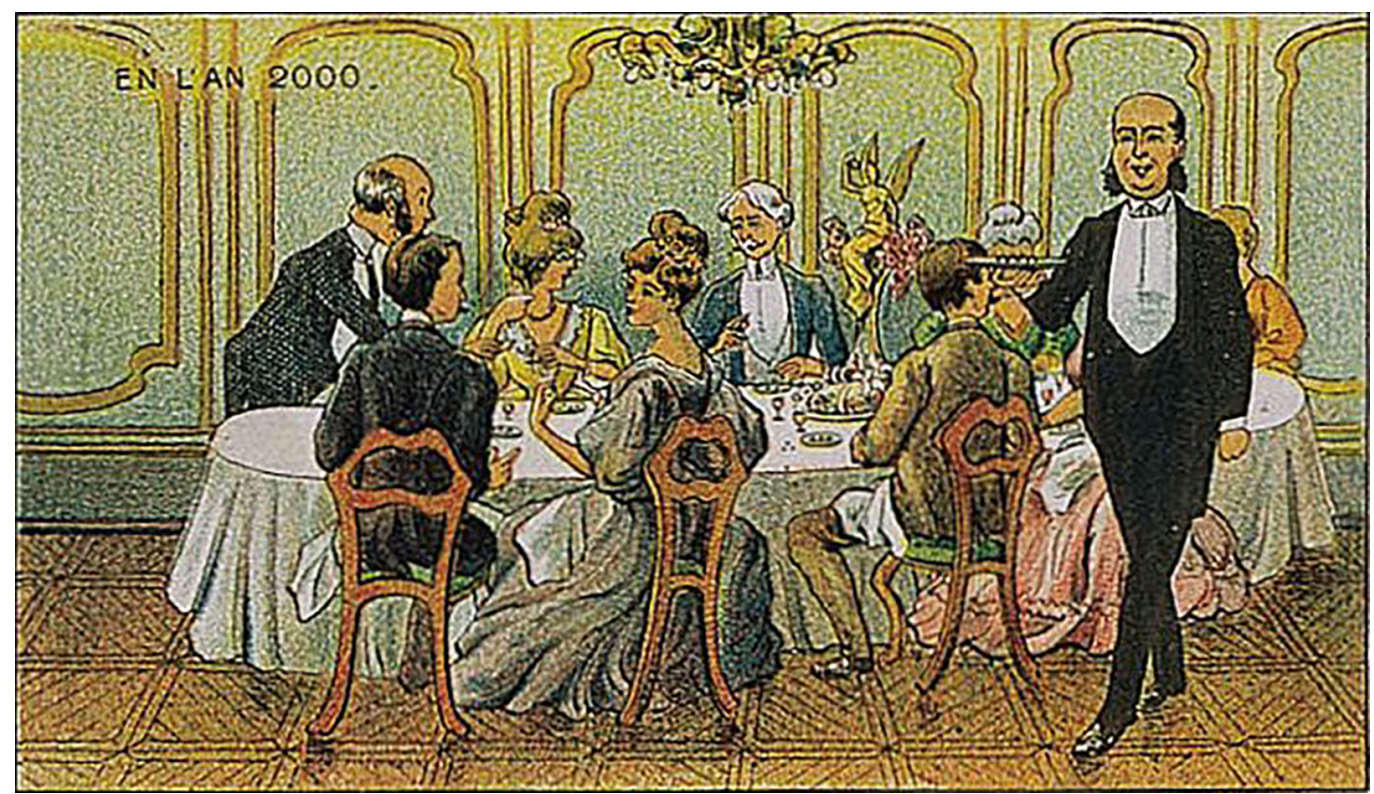

Imagining the future of food

In literary fiction first and then in cinema, the attitude towards food and the ways of producing and using it has changed a lot in the last 150 years.

In I888, in Looking back 2000- I 887, author Edward Bellamy, among his many insights, imagined, in line with his socialist thinking, utopian public kitchens where you could eat for free after retiring at 45 . Sixty years later, the obsession with optimization and efficiency filled tales of tables set with pills and surrogates, while starting in the 1970s, out of fear of running out of food due to the overpopulation of the Earth, science fiction authors turned to algae, insects, and alternative protein sources [Novak 20 I 4]. 
Among futurologists, those who grappled with the difficult task of translating some theoretical speculation based on scientific discoveries or experimental technologies into signs had to re-meditate their own scopic regime based on the visual culture of the time with the need to illustrate a verisimilar future.

Where the writer of genre novels could afford nuanced visions, the illustrator had to find exact forms and design opportunities based on a "creative" interpretation of certain frontier technologies.

This is the case, for example, of Jean Marc Cotè, who starting in 1899, together with other colleagues and collaborators [I], attempted to represent, on postcards inserted inside cigarette packs, some visions of what life would be like in the then distant year 2000. Among the scenes of life depicted, could not miss the representation of a lunch of the 2000s based on pills and candy. The discovery of the existence of vitamins dates back to I896, i.e. three years before this cartoon, while already during the 19th century it was discovered that food was composed of proteins, fats and carbohydrates.

The illustrator was evidently aware of these discoveries and thus depicts a traditional table occupied by guests in the clothes of the time and served by waiters equipped with trays containing only pills (fig. I). Another postcard shows what must have been the laboratory where these pills were 'cooked'. A laboratory populated by stills, tanks and other chemical equipment rather than pots and pans and cooking utensils (fig. 2).

In both pictures the author prefigures what will be a common practice in the 20th centu$r y$, that is, the molecular decomposition of food, not so much to feed during meals (if not in alternative forms, think for example of protein and vitamin supplements) but rather to adulterate crops or farms with vitamins and minerals or other forms of chemical additives.

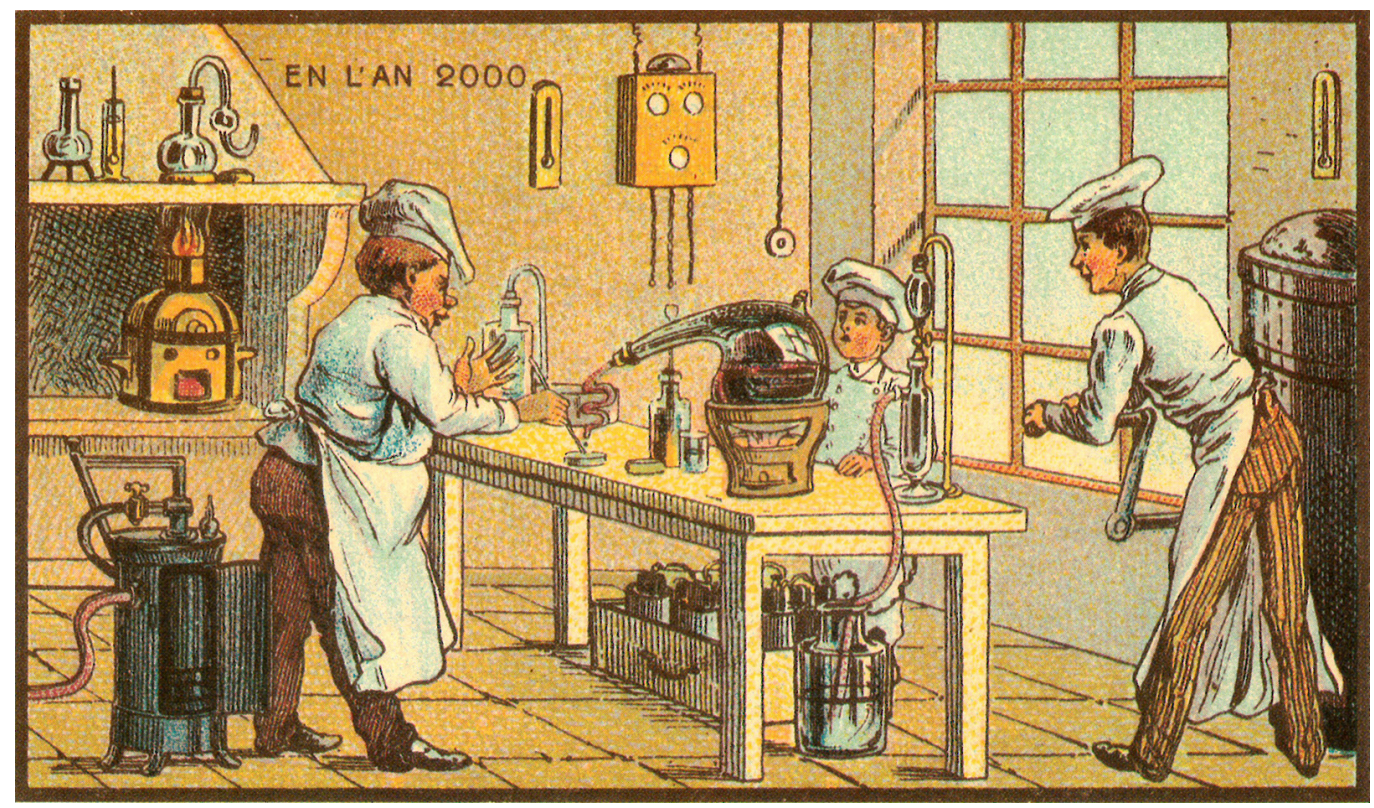

\section{Arthur Radebaugh}

About 60 years later, an illustrator, known mostly because he was among the first to use the airbrush in an artistic form, ventured into the same predictive exercise [2].

He would become, in the immediate post-war period, one of the symbolic characters of an optimistic techno-utopia. 
He is Arthur Radebaugh (fig. 3). Born in 1906 in Michigan, he moved to Chicago to attend the Chicago Art Institute in 1925, a school that allowed him to experiment with the use of the areograph but that he abandoned prematurely. His passion for drawing did not fade, quite the contrary, so much so that in the mid-thirties, he established himself as a successful freelance illustrator, working for United AirLines, and Burlington-Pacific Road and magazines such as Esquire and MoToR.

During the Second World War, he enlisted in the Army Ordinance Department, where he put his visionary talents to use in the Design \& Visualization department, tasked with imagining new types of war instruments. It is here, working side by side with scientists and engineers, that he probably formed his ability to translate on paper, and in a strong technological key, some visions of the near future.

To him we owe the use, inside the cockpits of war vehicles, of black lights to 'illuminate' so that they were not noticed by enemies, dashboards and driving instruments.

His experience in the army helped to enrich his skills and his drawing style, so much so that he embarked full-time on the activity of illustrator in the future.

In 1958, in fact, he began his production of illustrated vignettes with the enlightening title Closer Than We Think, in which, on the basis of scientific knowledge acquired during continuous travel between research centers and university laboratories, he drew impossible scenarios of domestic and working life. His drawings reached about nineteen million readers per week over a period of time between 1958 and 1962, when, due to health problems, he was forced to stop his production [3].

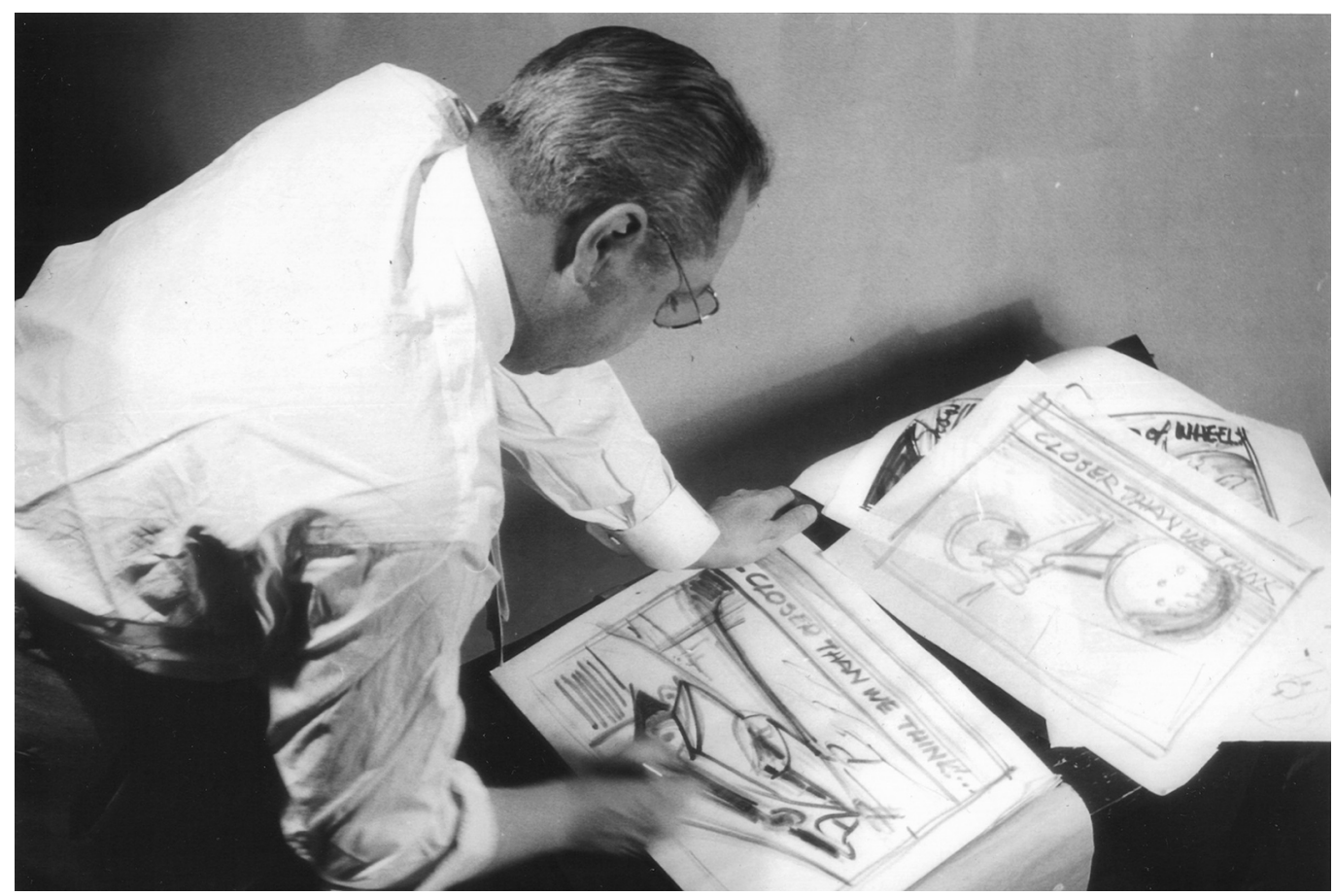

\section{Closer Than We Think}

Conceived to be syndicated in American and Canadian newspapers, the Closer Than We Think series is a perfect compendium of the possibilities of what life could potentially be like in the near future.

Radebaugh's interpretation combined the streamline code of which the design culture in the United States in the 1960s was still imbued, with the suggestions generated by the real advances in science and technology. 
From a graphic point of view, the composition of the vignette respected an almost constant layout. The strip consisted of a colored illustration accompanied by a block of text where the author added data, names of scientists or laboratories, the reading and understanding of what was illustrated. To complete the composition, the title in capital letters of the series on a colored rectangle placed at the top of the long side of the overall footprint rectangle. Among the more than one hundred vignettes drawn, those that foreshadow changes in the way food is produced, distributed or assimilated are about a dozen.

There are three sub-themes and they essentially answer three questions. How will we satisfy the growing demand for food due to the increase in world population?

How will retail food supply chains be reorganized? What will be the ways of preparing and consuming food in the kitchen?

The first question is answered by a series of vignettes that address the issue of industrialization and agricultural automation. In Factory Farms, a cartoon published in 196I, what we would today call a smart farm is depicted with a perspective view showing a circular building in the center of the scene. This appears to be the control center that governs the activity of automatically transferring feed from five huge plastic silos to the livestock barns, while an overhead monorail train transports material from one part of the farm to the other. In the foreground, however, the scene shows a researcher, in his laboratory, in the act of pricking a tomato with a syringe, the result of some experiment that has conspicuously increased its size (fig. 4).

The gigantism of the products of the earth and the overcoming of the seasonality of the crops are topos that also recur in another cartoon of 1962 entitled Colossal Crops in which the nuclear radiations, coming from an antenna that emits gamma rays, feed and make the flowers of the maize grow excessively, so much so that it is necessary to use self-propelled cranes and tractors in order to harvest them (fig. 5). In Fat Plants and Meat Beets, Radebaugh instead hypothesizes that in the near future, the growth of the population will force to replace, or at least flank, meat with flavored proteins of vegetable origin (fig. 6).

In the vignettes devoted to food distribution, Radebaugh is concerned with illustrating how food is retailed. The recurring image is that of self-service declined in different forms. In Corner Grocermat, the illustration shows a futuristic food market stand consisting of an elongated covered structure with two rings. In the lower ring, cases full of foodstuffs are

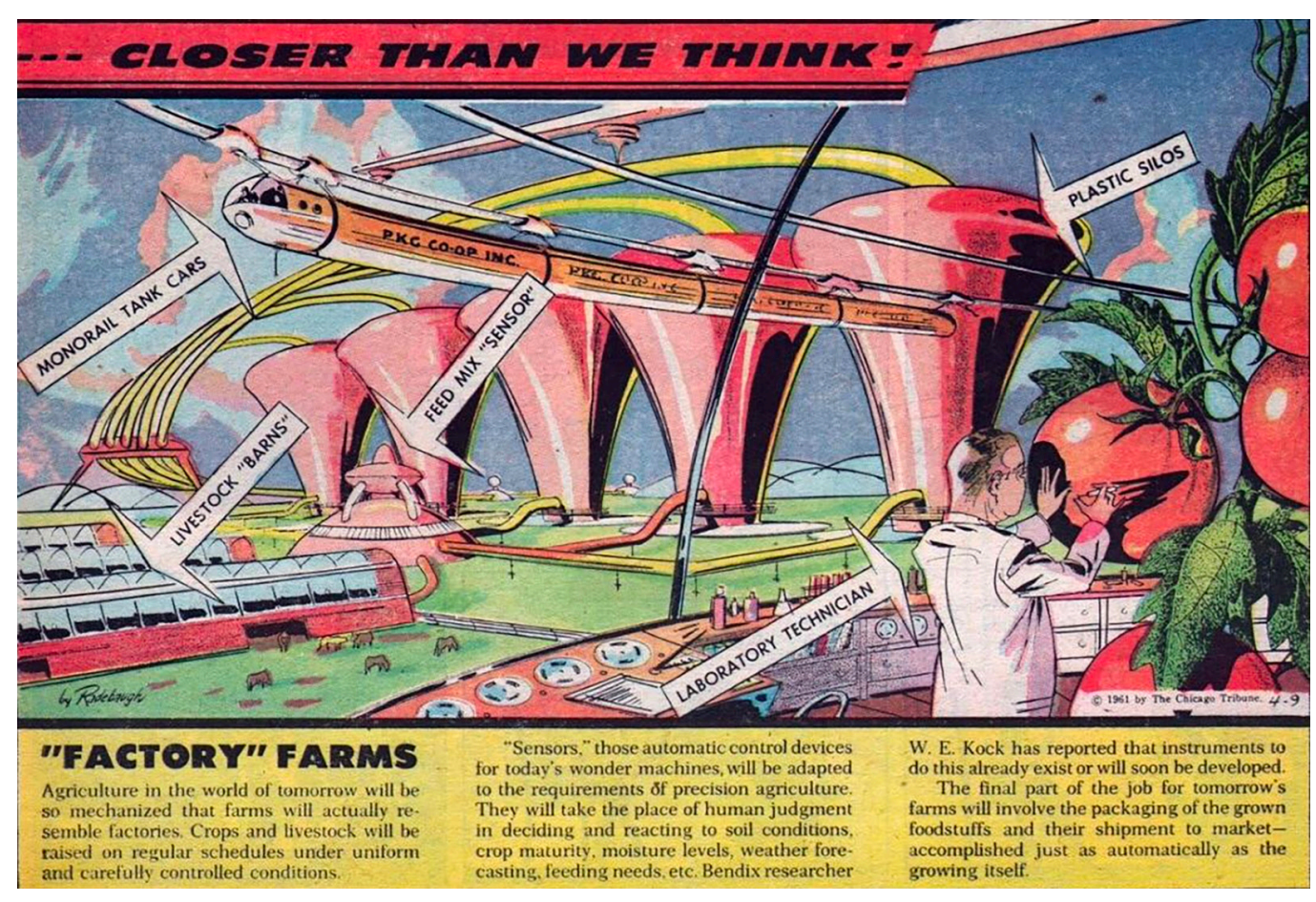




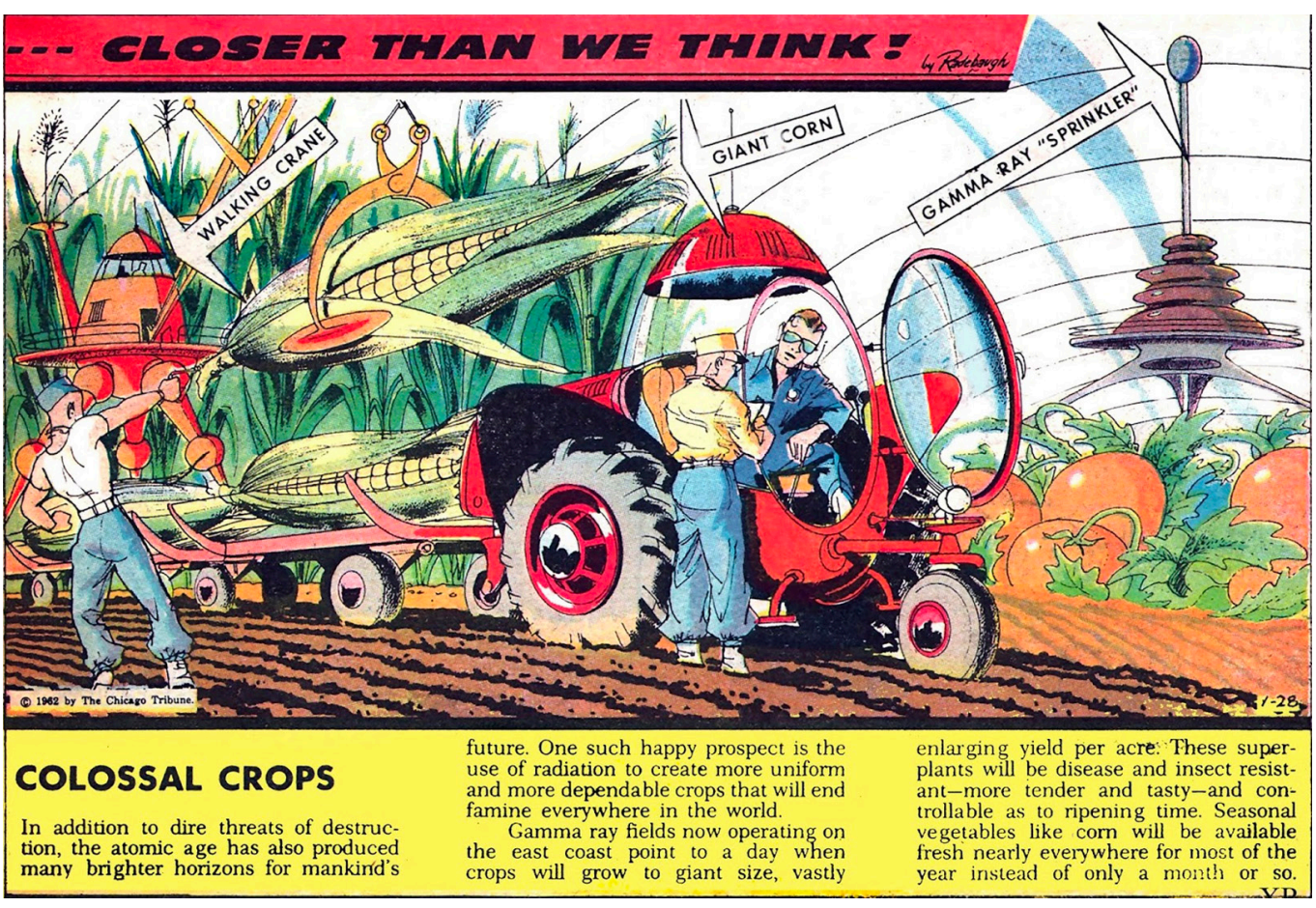

loaded by means of futuristic streamlined vehicles, while in the upper ring a conveyor belt takes the items selected by users to the checkout counter. Without getting out of the car, users indicate to operators which product they wish to purchase (fig. 7). Similarly, the DriveIn Supermarket can be considered an evolution of the Grocermat Corner. In this case, the customer, arriving by car, would have parked in a special stall where, after reading the offers on the monitors, he would have placed his orders using a push-button panel.After ordering, the customer would move to another location for payment and to allow the salespeople to load the purchases directly into the trunk of the car (fig. 8).

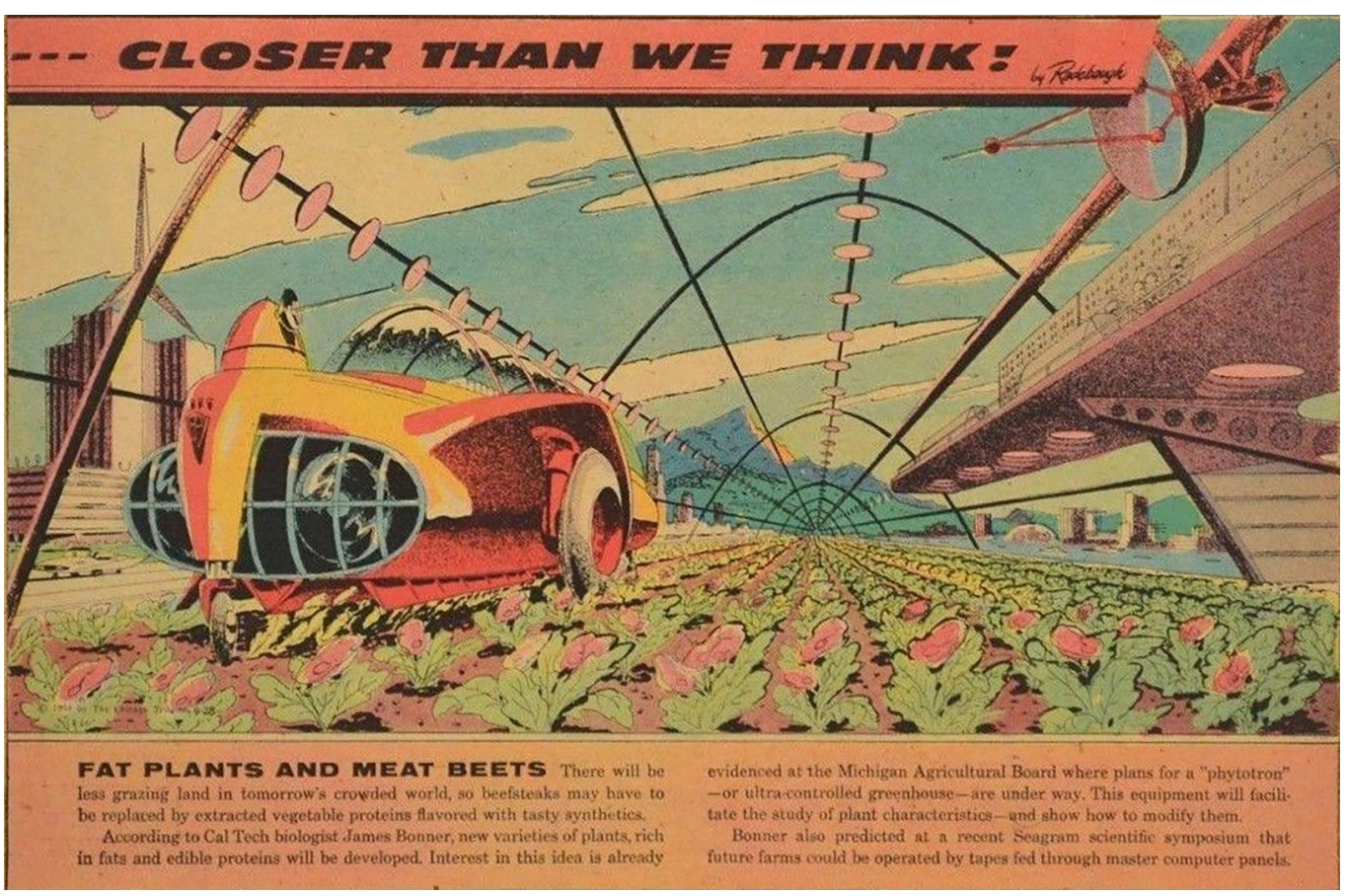


Fig. 7. Corner Grocermat, Closer Than We Think (1958).

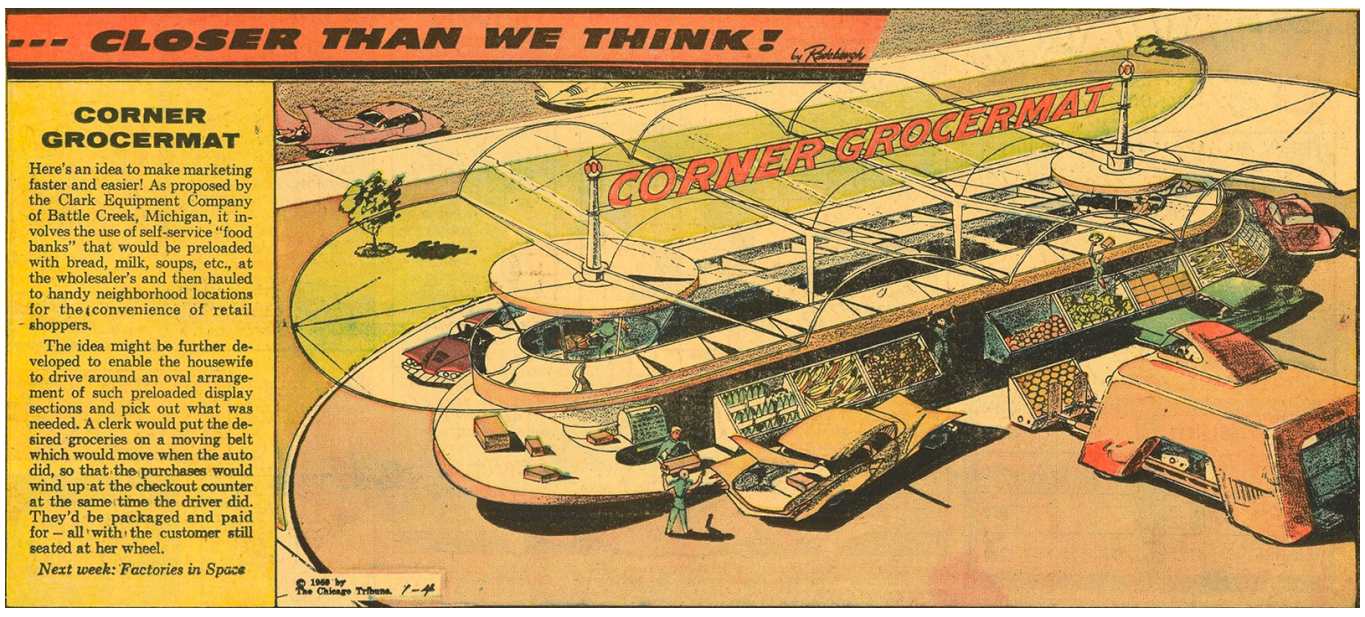

In All-Service Stations, Radebaugh's vision focuses instead on envisioning ready-to-eat, precooked food vending machines. These vending machines will complete the offer of the service stations of the future by catering to travellers while they wait for their cars to be refueled (fig. 9).

Finally, with regard to the preparation and consumption of food in the home, Arthur Radebaugh draws two vignettes, both of which emphasize the use of automatisms and robots that will be able, according to him, to help women in the kitchen. In particular, in Robot Housemaid a robot takes on the non-anthropomorphic form of a cone that moves around the house by means of air bearings, able to see around itself through cameras positioned on the tip of the cone and carrying dishes to be served on the table with a circular tray placed under the top of the cone (fig. I0). In Instant Cookers, we see a family sitting around a table occupied by a massive circular oven topped by a chrome hood and capable of instantly cooking a variety of selectable dishes, compartmentalized in the oven itself and selectable by touch. The rest of the vignette shows us from the large windows of the kitchen highway ramps and skyscrapers that seem to have come straight out of some Hugh Ferriss painting (fig. I I).

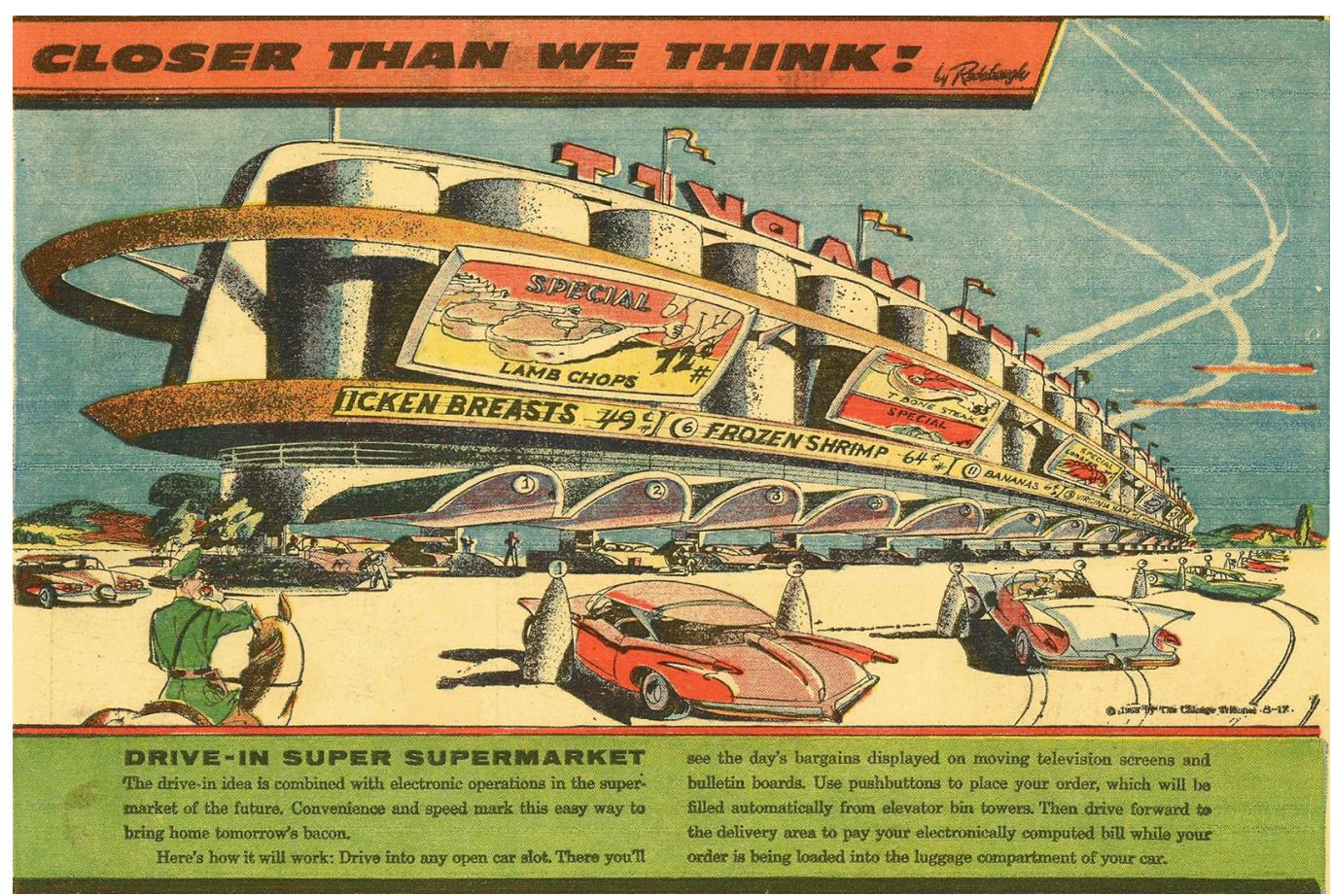


Fig. 9. All-Service Stations, Closer Than We Think (1959).

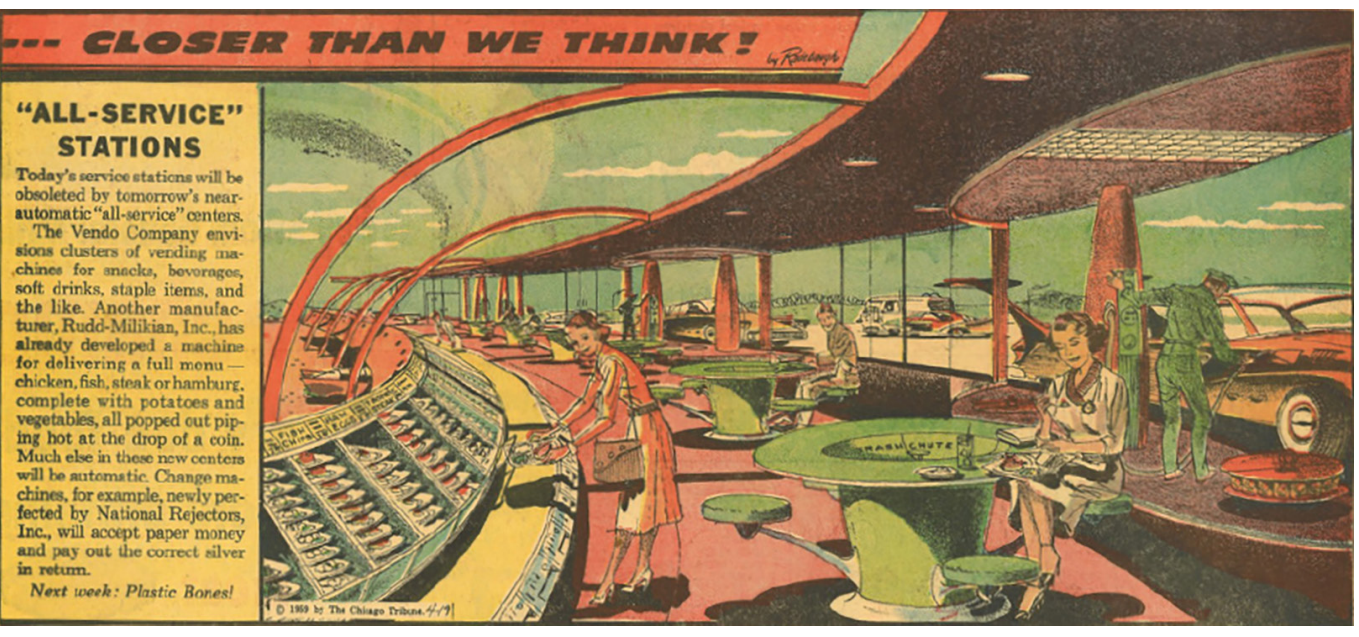

\section{Conclusions}

The experimentation of new design scenarios for food and wine heritage through the use of innovative technologies cannot but pass through the analysis of what were, in the past, the visions of the future [4]. Just like an archaeological excavation allows us to discover traces of a past lived, so the study of paleofuture helps us to understand certain scenarios filtered by the 'period eye' of that time. Everyone will have found, in the vignettes illustrated above, parallels and analogies with the technologies that actually developed and that legitimize the imaginative capacities of figures, such as those of Arthur Radebaugh, to imagine the future, prefiguring scenarios of daily life.

The purpose of this analysis, however, is not pure anecdotal. Domestic robots, vending machines, GMO foods, microwaves, conveyor belts or protein additives have permanently entered our lives as anticipated by many scientists. Radebaugh's merit was to have put on paper some intuitions and technological discoveries, or to have been able to imagine different uses of such technologies. Drawing, in this case "vision drawing", represents once again a privileged place for project experimentation and a territory of formative experience.

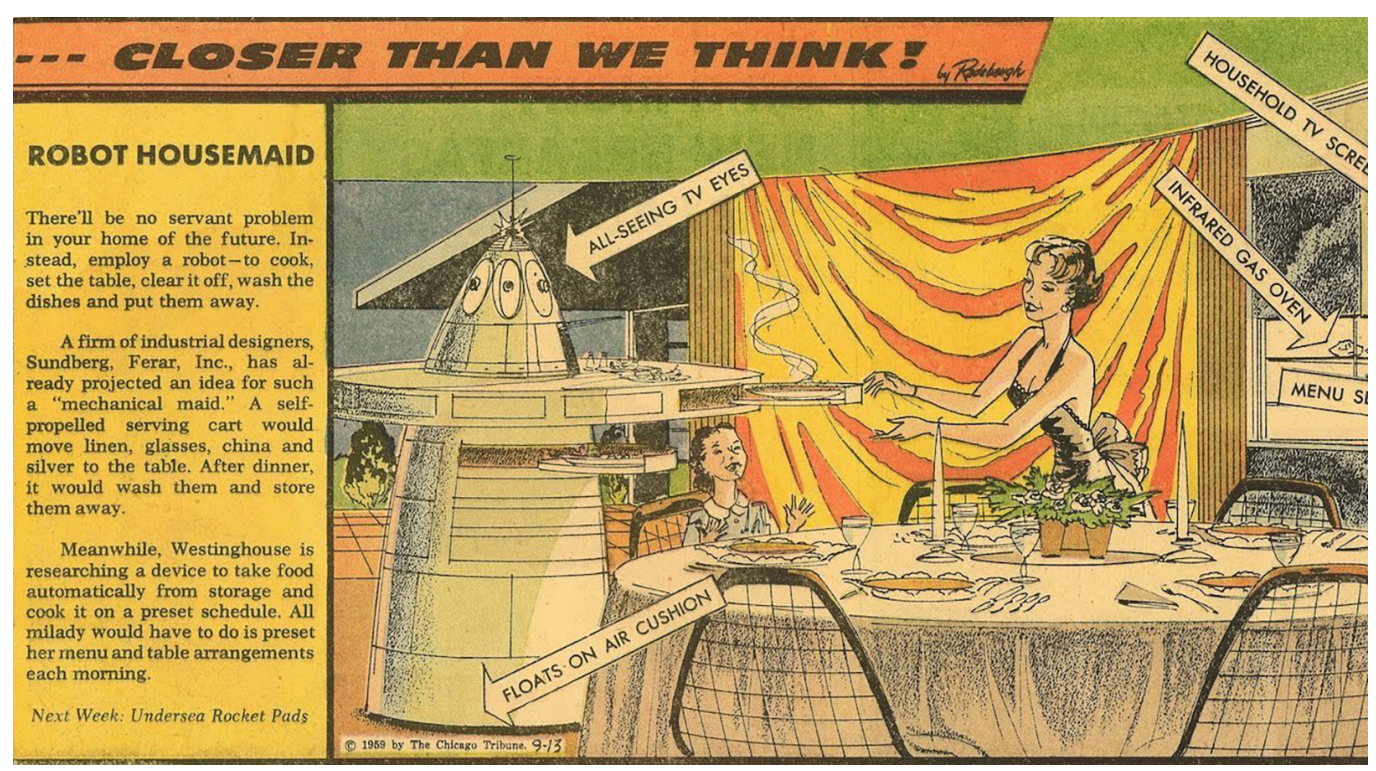

Fig. 10. Robot Housemaid, (1959).
(1oser Th 


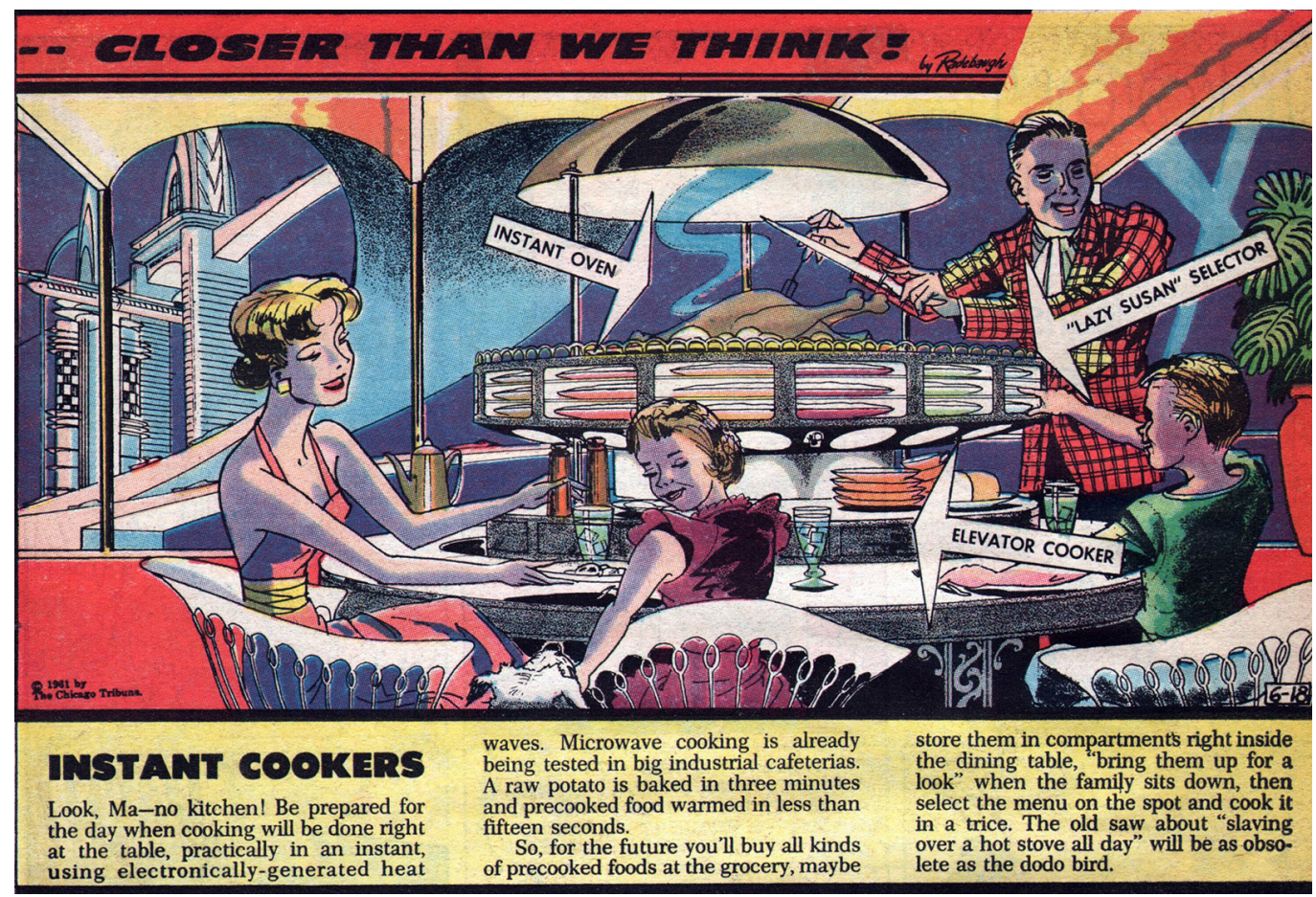

Notes

[I]The series is entitled En l'an 2000 and should have celebrated the advent of the twentieth century. The attribution of the vignettes is uncertain. Asimov [1986] argues that Cotè is the author of all the postcards while more likely there are several authors as can be easily guessed from some graphic differences and setting. Wikimedia Commons in <https://commons. wikimedia.org/wiki/Category:France_in_XXI_Century_(fiction)?uselang=en> (accessed 202I, February 2I) attributes them to three different authors: J. M. Cotè, J.Villemard, and F. Foliot.

[2] The confident use of the airbrush, together with that of black light, led a journalist from a Portsmouth newspaper in 1947 to use the term imagineering, many years before it was 'patented' by Disney. In the article, entitled Black Light Magic, Radebaugh's skill in combining artistic genius and technologically advanced instruments was emphasized. See <https://paleofuture.gizmodo. com/word-origins-imagineering-1940s-512630618> (accessed 2021, February 20)

[3] Arthur Radebaugh died in poverty in 1974 and his work forgotten until $200 \mathrm{I}$ when Tod Kimmel accidentally came into possession of the negatives of most of his collection. The full story of Arthur Radebaugh's 'rediscovery' was told in director Brett Ryan Bonowicz's 2018 documentary CloserThan We Think.

[4] The author of this paper is PI of a research project entitled Food and Wine Heritage in the Marche Region: Digital Storytelling Through Virtual and Augmented Reality funded under the call established by the University of Camerino for the allocation of the 2018 Ateneo Fund (FAR). Duration: 24 months (I/2/20I9 - I/2/ 202I). 


\section{References}

Asimov I. (1986). Futurdays. London:Virgin Books.

Belasco W. (2006). Meals to Come. Oakland: University of California Press.

Corn J.J., Horrigan B. (1984). Yesterday Tomorrow, Past Vision of the American Future. Baltimore: Johns Hopkins University Press.

\section{Website}

Novak M. (I 8 novembre 20 I4). Meal-in-a-pill:A staple of science fiction. <https://www.bbc.com/future/article/20 I 2022 I -foodpills-a-staple-of-sci-fi> (accessed 2021 February 20).

<http://arthur-radebaugh.blogspot.com/ > (accessed 202I February 20)

Novak M. (Ed.). Paleofuture Magazine, Issue I: Food. <https://paleofuture.com/blog/20 I |/4/4/paleofuture-magazine-issue-l-food.html> (accessed 202I February 20).

\section{Author}

Daniele Rossi, Università di Camerino, daniele.rossi@unicam.it

To cite this chapter: Rossi Daniele (2021). CloserThan We Think: visioni del futuro dell'alimentazione nelle illustrazioni di Arthur Radebaug . Closer Than We Think: visions of the future of food in the illustrations of Arthur Radebaugh. In Arena A., Arena M., Mediati D., Raffa P. (a cura di). Connettere. Un disegno per annodare e tessere. Linguaggi Distanze Tecnologie. Atti del $42^{\circ}$ Convegno Internazionale dei Docenti delle Discipline della Rappresentazione/Connecting. Drawing for weaving relationship. Languages Distances Technologies. Proceedings of the $42^{\text {th }}$ International Conference of Representation Disciplines Teachers. Milano: Franco Angeli, pp. $1085-1104$ 